\title{
Application of Phytotests to Study of Environmental Safety of Biologicaly Synthetised Au and Au/ZnO Nanoparticles Using Tanacetum parthenium Extract
}

\author{
Marcin Szymanski ${ }^{1}$ Renata Dobrucka ${ }^{2}$
}

Received: 22 October 2021 / Accepted: 6 December 2021 / Published online: 18 December 2021

(c) The Author(s) 2021

\begin{abstract}
Due to their small sizes and high reactivity, nanoparticles have a completely different toxicity profile than larger particles, and it is difficult to predict their potential ecological impact. There is a need for broad ecotoxicological studies of nanomaterials in order to specify their environmental impact and ensure safe application of nanotechnology products. In this work, we have assessed the toxicity of $\mathrm{Au}$ and $\mathrm{Au} / \mathrm{ZnO}$ metal nanoparticles obtained with the use of Tanacetum parthenium (herba) extract. The obtained nanoparticles were characterized by UV-Vis spectrophotometry (UV-VIS), Transmission electron microscopy (TEM), Atomic force microscopy (AFM), and Fourier transform infrared spectroscopy (FTIR). In order to assess the toxicity of biologically synthesized nanoparticles, we used seeds of various plants: Lepidium sativum, Linum flavum, Zea mays, Salvia hispanica-chia, Lupinus angustifolius, Petroselinum crispum subsp. Crispum, Beta vulgaris, Phaseolus vulgaris. The in vitro phytotests showed that gold nanoparticles at a specific range of concentrations for all plants stimulated their growth. The highest growth activity was exhibited by the solution at the concentration of $0.300 \mathrm{mg} / \mathrm{ml}$ towards corn $(\mathrm{Aw} \approx-135 \pm 16)$ and flax (Aw $\approx-44 \pm 10$ ). Only for parsley the IC50 was determined at $0.57 \mathrm{mg} / \mathrm{ml}$, but solutions at the concentration of 0.030 to $0.150 \mathrm{mg} / \mathrm{ml}$ also stimulated plant growth. $\mathrm{Au} / \mathrm{ZnO}$ had a toxic effect at all concentrations applied in the study.
\end{abstract}

Keywords Au nanoparticles $\cdot \mathrm{Au} / \mathrm{ZnO}$ nanoparticles $\cdot$ Tanacetum parthenium $\cdot$ Phytotoxicity $\cdot$ IC50

\section{Introduction}

Nanotechnology has brought a breakthrough for science and engineering as regards production of smaller materials with important electronic, physical and chemical properties at the atomic level [1-3]. Therefore, in the last 20 years, the industry has become much more involved in nanotechnology and manufacturing of nano-enabled products $[4,5]$. One interesting solution offered by nanotechnology involves metal nanoparticles [6-8]. As the particle size is reduced to the size of single atoms, the biological activity of the particles increases $[9,10]$. Compared to materials in the microscale,

Renata Dobrucka

renata.dobrucka@ue.poznan.pl

1 Centre for Advanced Technologies, Adam Mickiewicz University in Poznań, ul. Uniwersytetu Poznańskiego 10, 61-614 Poznan, Poland

2 Department of Industrial Products and Packaging Quality, Institute of Quality Science, Poznań University of Economics and Business, al. Niepodległości 10, 61-875 Poznan, Poland nanoparticles have a more developed actual surface and a significantly higher number of surface active groups with a greater biological potential [11-13]. Due to their small sizes and high reactivity, nanoparticles have a completely different toxicity profile than larger particles, and it is difficult to predict their potential ecological impact. For years, researchers have been conducting experimental studies to assess the environmental risk created by nanoparticles.

Despite that, our knowledge of the influence of nanoparticles on the development of plants is still incomplete. What we are missing is, among others, unified information. It is necessary to conduct further studies on the nanoparticle uptake, translocation and accumulation in plants because the present knowledge in this matter is not consistent, which precludes drawing simple conclusions. This situation is probably the consequence of variable physicochemical parameters of the used nanoparticles (surface charge and area, diameter, capping agents), as well as their type, parameters of incubation (time and concentration), and different conditions of growth (e.g. solid, hydroponic or in vitro culture), 
and the use of different plant species, organs and tissues in the studies [14].

It is very important to have knowledge of the negative effects that nanoparticles can have on living organisms, including plants. Plants have been used for years as bioindicators in the assessment of potential environmental threats. When nanoparticles are absorbed by plants, they are translocated throughout the plant and cause significant damage. A distinctive feature of nanoparticles is their size, which is smaller than the size of cells and cellular organelles. This characteristic is unusual and makes it possible for nanoparticles to penetrate basic biological structures [15]. Moreover, plants are indispensable in all ecosystems, and through vegetables and fruits they serve as a point through which nanoparticles enter the food chain. Nanoparticles present in the environment can be absorbed through the roots, and then translocated to the shoots and leaves through the vascular system. Due to their sizes, nanoparticles can cross plasma membrane, interact with protoplast and cellular component, and disrupt normal cell function [16].

Even though the exact mechanisms in which nanoparticles impact the natural environment have not been identified and the state of knowledge on toxicity remains poor, the development of nanomaterials should not be impeded. However, all efforts must be made to identify and assess their possible toxic effects. Thus, in this work, we assessed the toxicity of biologically synthesized $\mathrm{Au}$ and $\mathrm{Au} / \mathrm{ZnO}$ nanoparticles. We assessed the toxicity of prepared nanoparticles using an in vitro toxicity test. In the studies, we used 9 seeds of different plants: Lepidium sativum, Linum flavum, Zea mays, Salvia hispanica-chia, Lupinus angustifolius, Petroselinum crispum subsp. Crispum, Beta vulgaris, Phaseolus vulgaris. The measured values of shoot growth or its inhibition, compared to the control sample, served as the basis for creating the charts showing the dependence of growth activity (Aw) \{100.(growth length of a respective seed - average length of the control sample)/average length of the control sample\} on concentration (C). The IC50 was calculated on the basis of the equation: $\mathrm{Aw}=\mathrm{a} \cdot \mathrm{C}+\mathrm{b}$.

\section{Materials and Methods}

\subsection{Materials}

The studies were carried out with the use of reagents purchased from Sigma-Aldrich (Poland). The studies were conducted with the use of demineralized water (J.T. Baker) and Aerosil 200 (Evonik Resource Efficiency GmbH; CAS no. 112945-52-5). The study used the seeds of: garden cress, L. sativum (manufacturer: BIO Garden ress - Certified ecological seeds), golden flax, L. flavum (Bio Planet), corn - Rywal variety, Z. mays (Kieleckie Przedsiębiorstwo
Nasienne "Centrala Nasienna" Spółka z o.o. in Kielce), chia, S. hispanica-chia (GutBio), narrowleaf lupine of Karo variety, L. angustifolius (PPH Centnas Sp.z o.o. in Krotoszyn), curly parsley Moskrul 2, P. crispum subsp. crispum (Vilmorin Garden Sp. z o.o.), beetroot red sphere 2, B. vulgaris (Legutko), dwarf common string bean Złota Saxa, P. vulgaris (Legutko).

\subsection{Synthesis of Au and Au/ZnO Nanoparticles}

Two kinds of solutions were prepared for phytotoxicity studies: of Au nanoparticles and $\mathrm{Au} / \mathrm{ZnO}$ nanoparticles. First, a water extract of Tanacetum parthenium was prepared. It was made by combining $25 \mathrm{~g}$ of powdered herb and $100 \mathrm{ml}$ of double distilled water. The extract was stirred for $50 \mathrm{~min}$ at $85^{\circ} \mathrm{C}$, and was used immediately after filtration through Whatman's No. 1 filter paper. The nanoparticle solution was prepared with $5 \mathrm{mM} \mathrm{HAuCl}_{4}$ combined at a 1:1 ratio with the obtained extract. Then, the solution of $\mathrm{Au} / \mathrm{ZnO}$ nanoparticles was prepared. The nanoparticles were obtained using $5 \mathrm{mM} \mathrm{HAuCl}_{4}$, and $5 \mathrm{mM} \mathrm{ZnNO}_{3}$, and combined at a 1:1 ratio. The obtained solution was stirred at $60{ }^{\circ} \mathrm{C}$. After 12 , 24 and $48 \mathrm{~h}$ of stirring, the absorbance of the solution was analyzed.

\subsection{Characterization Methods of $\mathrm{Au}$ and $\mathrm{Au} / \mathrm{ZnO}$ Nanoparticles}

In order to measure the maximum absorbance of the synthesized nanoparticles, UV-Vis spectrophotometry was used. The optical properties of the synthesized nanoparticles were analyzed using the ultraviolet and visible absorption spectroscopy (spectrophotometer Cary E 500) at the range of $300 \mathrm{~nm}-800 \mathrm{~nm}$. The binding properties of $\mathrm{Au}$ and $\mathrm{Au} / \mathrm{ZnO}$ nanoparticles synthesized using $T$. parthenium extract were identified by means of Fourier transform infrared spectroscopy (FTIR) analysis. A Transmission electron microscope JEOL JEM 1200 EXII operating at $80 \mathrm{kV}$ was used to determine the shape, size and microstructures of $\mathrm{Au}$ and $\mathrm{Au} / \mathrm{ZnO}$ nanoparticles. TEM uses a beam of electrons that passes through a very thin specimen and enters into an interaction with it. When electrons are highly accelerated (to several hundreds of $\mathrm{keV}$ ) and focused on the material, they can scatter or backscatter (elastically or inelastically), enter into various kinds of interactions and emit signals, e.g. X-rays, Auger electrons or light. The study was performed with the use of the atomic force microscope INTEGRA SPECTRA SOLAR of NT-MDT brand and measurement tips for NSGO1 highresolution measurements, in the tapping mode. The resonance frequency of the tips was from 87 to $230 \mathrm{kHz}$. The force constant was from 1.45 to $15.1 \mathrm{~N} / \mathrm{m}$. The scanning area was $10 \mu \mathrm{m} \times 10 \mu \mathrm{m}$, with $1000 \times 1000$ scanning points. 


\subsection{Phytotoxicity Studies}

In this work, we studied the toxicity of the obtained nanoparticles as well as the extract itself. In order to assess phytotoxicity, we prepared dilutions of T. Parthenium extract at the following concentrations: $0.875 ; 1.750 ; 2.188$; $4.375 ; 8.750 ; 10.50 \mathrm{mg} / \mathrm{ml}$, solution of Au nanoparticles: 0.003; 0.030; 0.075; 0.150; 0.300; $0.750 \mathrm{mg} / \mathrm{ml}$, solution of $\mathrm{Au} / \mathrm{ZnO}$ nanoparticles: $0.010 \%-0.0003 / 0.003 ; 0.100 \%$ $0.003 / 0.030 ; 1.000 \%-0.030 / 0.300 ; 2,500 \%-0.075 / 0.750$; $5.000 \%-0.150 / 1.500 ; 10.00 \%-0.300 / 3.000 \mathrm{mg} / \mathrm{ml}$. The appropriate substrate was prepared as well (20.0 g of Aerosil combined with $200 \mathrm{ml}$ of each dilution of the stock solution, stirred until they achieved a uniform consistency). Demineralized water was used as a reference sample. Depending on their size, from 10 to 50 selected seeds were transferred to the substrate. Then, depending on their kind, the seeds were stored in an incubator (laboratory incubator 45L PRO) $\left(23{ }^{\circ} \mathrm{C}\right)$ for: $120 \mathrm{~h}$ (chia, lupine, garden cress), $144 \mathrm{~h}$ (bean, flax, corn), $168 \mathrm{~h}$ (beetroot) and $264 \mathrm{~h}$ (parsley). After incubation, the shoot growth was measured. The measured values of shoot growth or its inhibition, compared to the control sample, served as the basis for creating the chart showing the dependence of growth activity (Aw) $\{100 *$ (growth length of a respective seed - average length of the control sample)/average length of the control sample $\}$ on concentration (C). The IC50 (i.e. the concentration at which the growth of the test plant was inhibited by 50\%) was calculated on the basis of the equation $A w=a \cdot C+b$. The linear range of A (C) dependence was determined from the whole range of the studied concentrations on the basis of a logarithmic dependence $\mathrm{A}=\mathrm{a} \cdot \ln (\mathrm{C})+\mathrm{b}$.

\section{Results and Discussion}

\subsection{UV-VIS Analysis}

Figure 1 presents the $\mathrm{UV}-\mathrm{Vis}$ spectra of $\mathrm{Au} / \mathrm{ZnO}$ nanoparticles synthesized using $T$. parthenium extract. The absorbance was measured after 12, 24 and $48 \mathrm{~h}$ of synthesis. As the reaction time increased, the solution color changed, confirming the reduction of metals to the nano form. An important technique used in order to determine the formation of metal nanoparticles in an aqueous solution is UV-Vis spectroscopy. Using a spectrophotometer Cary E 500 with a quartz cell with $10 \mathrm{~mm}$ optical path length, UV-Vis (ultraviolet and visible light) absorption spectra were measured over a range of 300-800 $\mathrm{nm}$. Nanoparticles produced from extracts are subjected to three phases: activation, growth, and termination. During the activation phase, the elements of plant extract in the form of phytochemicals (with $-\mathrm{OH}$ groups), which have reduction capabilities, reduce the metal ion from

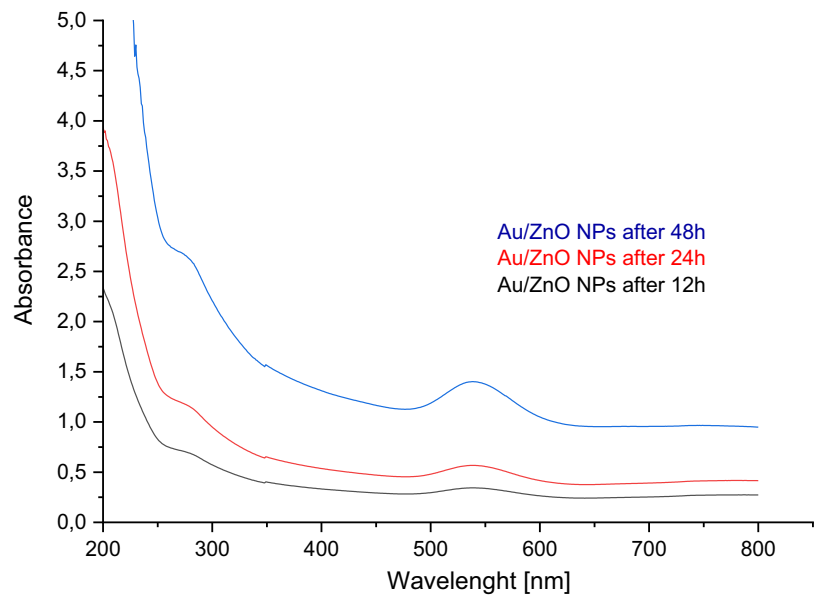

Fig. $1 \mathrm{UV}-\mathrm{Vis}$ spectra of $\mathrm{Au} / \mathrm{ZnO}$ nanoparticles synthesized using $T$. parthenium extract

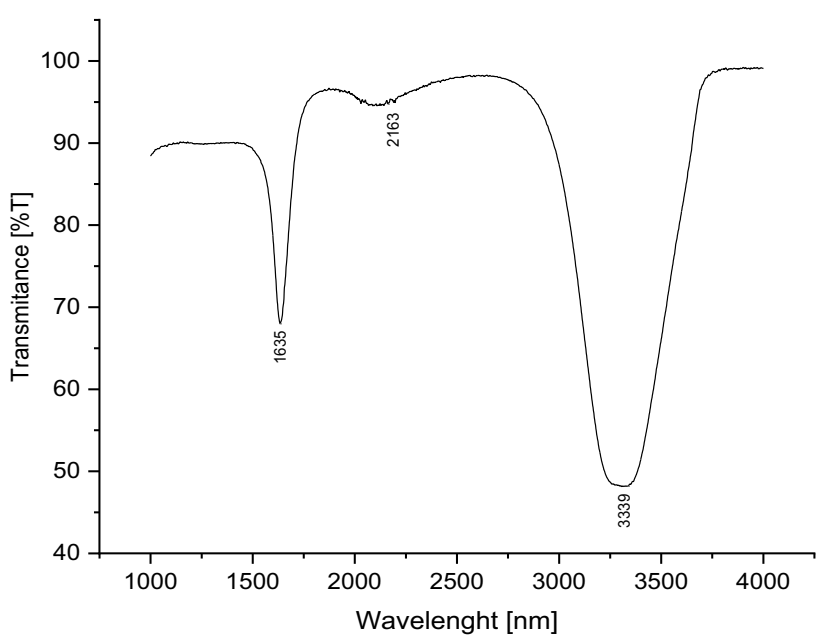

Fig. 2 FTIR spectra of the $\mathrm{Au} / \mathrm{ZnO}$ nanoparticles synthesized using T. Parthenium extract

their salt precursors to a zero-valent state, which is followed by metal atom nucleation. During this process of biological reduction, the separated atoms of metal start to associate together. As a result, the phase of growth intensifies thermodynamic permanence of nanoparticles as well as leads to accumulation of the synthesized nanoparticles and causes their morphological alteration. After $48 \mathrm{~h}$ of synthesis, we observed a clear peak at the length of $560 \mathrm{~nm}$, characteristic of nanogold. The peak at $330 \mathrm{~nm}$ was characteristic of nanoZnO.

\subsection{FTIR Analysis}

Figure 2 presents the FTIR spectra of $\mathrm{Au} / \mathrm{ZnO}$ nanoparticles synthesized from T. Parthenium extract. The FTIR measurement was used to search for the biomolecules present 
in $T$. parthenium extract that may be responsible for the capping and efficient stabilization of the synthesized $\mathrm{Au} /$ $\mathrm{ZnO}$ metal nanoparticles $[17,18]$. The spectra present bands at $3339 \mathrm{~cm}-1,2163 \mathrm{~cm}-1$ and $1635 \mathrm{~cm}-1$. A strong peak associated with the $\mathrm{O}-\mathrm{H}$ bond vibrations of the hydroxyl group was observed at $3339 \mathrm{~cm}-1$. The band at $2163 \mathrm{~cm}-1$ may suggest the presence of the alkynes group. The most intense band at $1635 \mathrm{~cm}-1$ is associated with amide bonds of proteins that may emerge due to carboxyl stretching. The studies confirm the presence of active compounds found in $T$. parthenium extract. It has been assumed that bioactive compounds are the reducing and capping agents for $\mathrm{Au} / \mathrm{ZnO}$ nanoparticles.

According to the literature, the T. parthenium is rich in biologically active substances, which is of key importance for the synthesis of nanoparticles. The main monoterpene ingredient of the overground parts of the plant is camphor. It also contains much smaller amounts of ester derivatives of chrysanthenol, verbenol and borneol. At present, it is generally believed that the most significant factor for biological activity and potential medical applications is the fraction of sesquiterpenoids (germacranes, guaianes and eudesmanes), considerable amounts of which are found in plant leaves. What is especially important is the content of unsaturated sesquiterpene lactones, and the main representative of that group, which can represent even $85 \%$ of its composition, i.e. parthenolide (belonging to germacranolide class), is considered a marker (the minimum level of this ingredient is usually determined at the limit of $0.2 \%$ ) that qualifies the usability of plant material [19]. The leaves and flowers of $T$. parthenium contain some lipophilic flavonoids, 6-hydroxykaempferol 3,6-dimethyl ether, 6-hydroxykaempferol 3,6,4'-trimethyl ether (tanetin), quercetagetin 3,6-dimethyl ether, quercetagetin 3,6,3'-trimethyl ether (accompanied by isomeric 3,6,4'-trimethyl ether), quercetin, apigenin (also apigenin 7-glucuronide), luteolin (also luteolin 7-glucuronide), chrysoeriol, santin, jaceidin, and centaureidin [20].

As well known, many polyphenolic and flavonoid compounds possess antioxidant properties, such as metal chelating and free radical scavenging capacities via inactivation of reactive oxygen species (ROS) and other free radicals produced by aerobic metabolism [21]. The presence of flavonoids is highly important for the formation $\mathrm{Au} /$ $\mathrm{ZnO}$ nanoparticles. The antioxidant properties of flavonoid compounds are associated with the ring-shaped structure of the particle, which contains conjugated double bonds, and also with the presence of various functional groups in the rings. The antioxidant activity of flavonoids stems from the presence of a considerable number of hydroxyl groups. The number and position of hydroxyl groups determine the intensity of their antioxidant effects. A greater number of hydroxyl groups increases the antioxidant properties of compounds. According to the studies conducted by [22], major polyphenolic acid compounds in $T$. parthenium with high antioxidant properties were characterized as 3,5-, 4,5- and 3,4-di- $O$-caffeoylquinic acids. The studies of [23] showed that the extract of $T$. parthenium without parthenolides exhibits free radical scavenging activity towards a wide range of reactive oxygen species, and a greater activity than vitamin C. Its oxygen and hydroxyl radical scavenging activity was five times higher than that exhibited by ascorbic acid, and iron free scavenging activity - three times higher than that of ascorbic acid. The authors showed that it exhibited the highest activity in scavenging iron radicals, and then, respectively, oxygen, hydroxyl and peroxy nitrate radicals.

Apigenin present in the herb promotes metal chelation, reduces free radicals, and induces apoptosis in many cancer cells. This compound is a strong inhibitor of ornithine decarboxylase - an enzyme important for impeding cancer development. It also contributes to the increase of intracellular concentration of glutathione, which is an endogenous defense factor against oxidative stress. It also contributes to the increase of intracellular concentration of glutathione, which is an endogenous defense factor against oxidative stress $[24,25]$.

\subsection{TEM Study}

In this work, the obtained nanoparticles were imaged by means of Transmission electron microscopy. TEM is a wellestablished method for observing the sizes and shapes of obtained nanoparticles. Transmission Electron Microscopy provides magnification that is much greater than in the case of conventional optical microscopes, which enables more detailed observation of the specimen. TEM uses a beam of electrons that passes through a very thin specimen and enters into an interaction with it. Figure 3 shows the TEM images of Au nanoparticles (A), (B) and $\mathrm{Au} / \mathrm{ZnO}$ nanoparticles (C), (D) synthesized using T. parthenium extract. It confirms the presence of spherical nanoparticles of both $\mathrm{Au}$ and $\mathrm{Au} / \mathrm{ZnO}$. We observed spherical gold nanoparticles of $5 \mathrm{~nm}$, and spherical $\mathrm{Au} / \mathrm{ZnO}$ nanoparticles of $7 \mathrm{~nm}$. We supplemented the observation of nanoparticles with further tests, i.e. using Atomic Force Microscopy.

\subsection{AFM Study}

Figure 4 shows AFM images (A, B, C, D) of $\mathrm{Au}$ and $(\mathrm{E}, \mathrm{F}, \mathrm{G}, \mathrm{H}) \mathrm{Au} / \mathrm{ZnO}$ nanoparticles synthesized using T. parthenium extract with (A, E) the topography of $10 \mu \mathrm{m} \times 10 \mu \mathrm{m},(\mathrm{B}, \mathrm{F})$ the topography of $1 \mu \mathrm{m} \times 1 \mu \mathrm{m},(\mathrm{C}$, G) the topography of $3 \mu \mathrm{m} \times 3 \mu \mathrm{m}$ and $(\mathrm{D}, \mathrm{H})$ the topography of $3 \mu \mathrm{m} \times 3 \mu \mathrm{m}$ with the profile. AFM microscopy makes it possible to obtain atomic-resolution images of the examined surfaces. An AFM microscope allows for the 
Fig. 3 TEM images of $\mathrm{Au}$ nanoparticles $(\mathbf{A}, \mathbf{B})$ and $\mathrm{Au} /$ $\mathrm{ZnO}$ nanoparticles $(\mathbf{C}, \mathbf{D})$ synthesized using $T$. parthenium extract

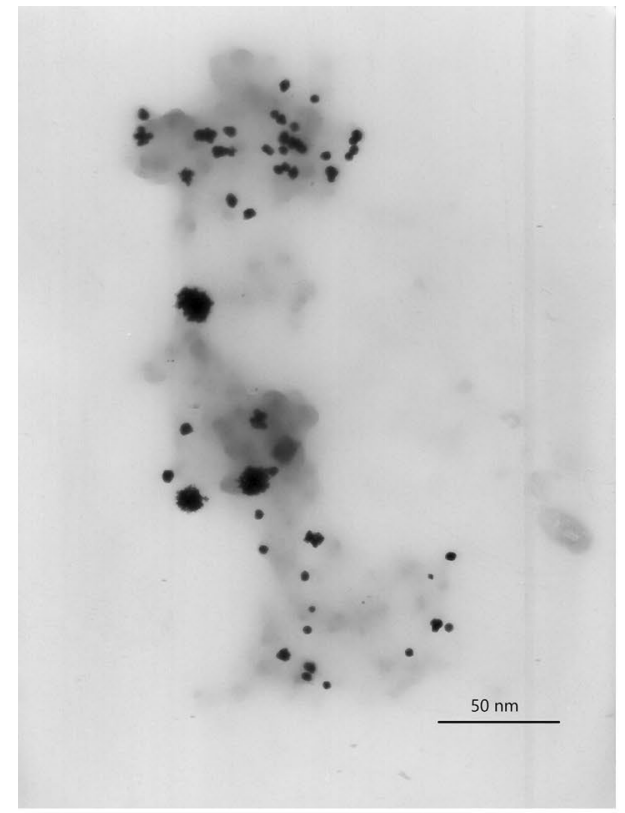

(A)

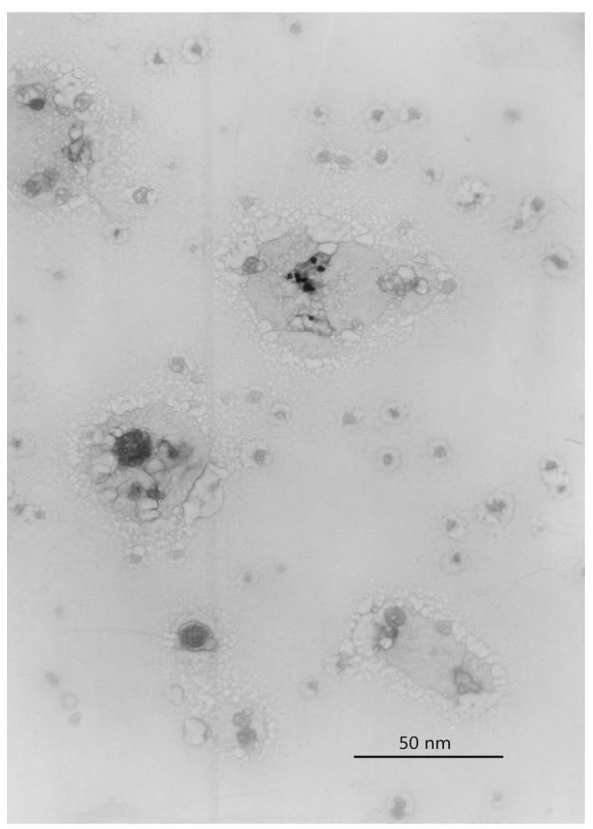

(C)

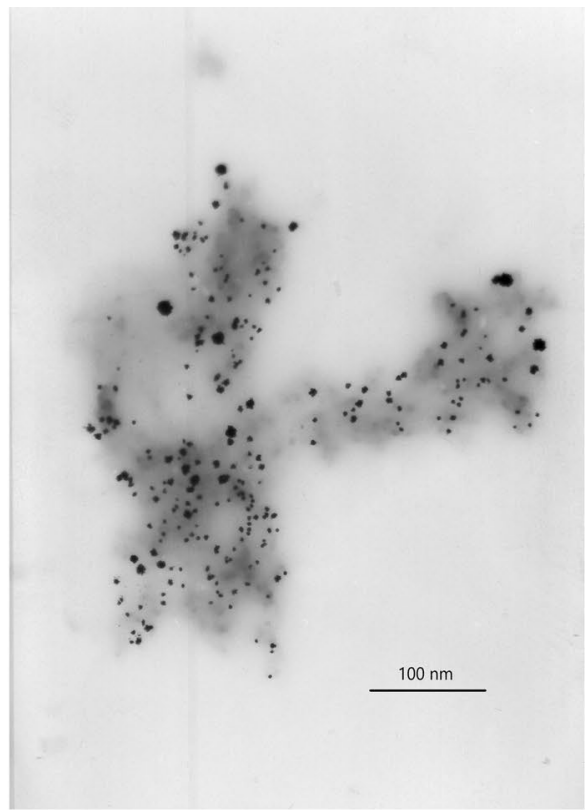

(B)

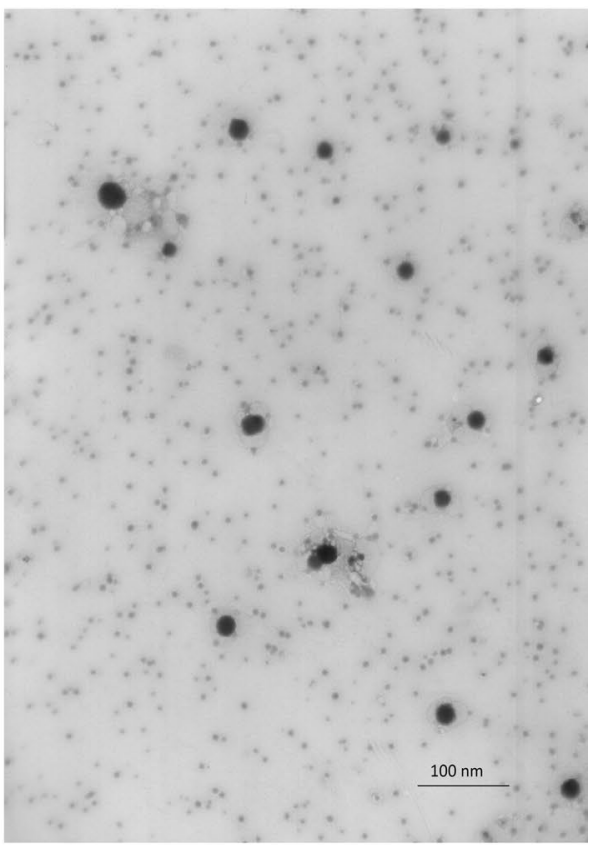

(D) examination of not only conductors and semi-conductors, but also non-conductors, which makes it distinct from other scanning microscopes. AFM microscopes also enable measurements in liquids, making it possible to examine live biological preparations in an environment that resembles their natural environment The studies confirmed the presence of Au nanoparticles of up to $5 \mathrm{~nm}$, as well as of $\mathrm{Au} / \mathrm{ZnO}$ nanoparticles of up to $7 \mathrm{~nm}$.

\subsection{Determination of the Inhibitory Concentration $50 \%$ (IC50)}

Phytotoxicity is important to understand the impact that manufactured nanomaterials may have on the environment (Kaur, 2018). As shown by the world literature, certain concentrations of most nanoparticles are toxic. In such circumstances, they impact crop productivity by altering their morphoanatomical, physiological, biochemical and genetic 
Fig. 4 AFM images (A-D)

of $\mathrm{Au}$ and $(\mathbf{E}-\mathbf{H}) \mathrm{Au} / \mathrm{ZnO}$ nanoparticles synthesized using $T$. parthenium extract the with $\mathbf{A}, \mathbf{E}$ the topography of $10 \mu \mathrm{m} \times 10 \mu \mathrm{m}, \mathbf{B}, \mathbf{F}$ the topography of $1 \mu \mathrm{m} \times 1 \mu \mathrm{m}, \mathbf{C}, \mathbf{G}$ the topography $3 \mu \mathrm{m} \times 3 \mu \mathrm{m}$ and $\mathbf{D}$, $\mathbf{H}$ the topography $3 \mu \mathrm{m} \times 3 \mu \mathrm{m}$ with the profile

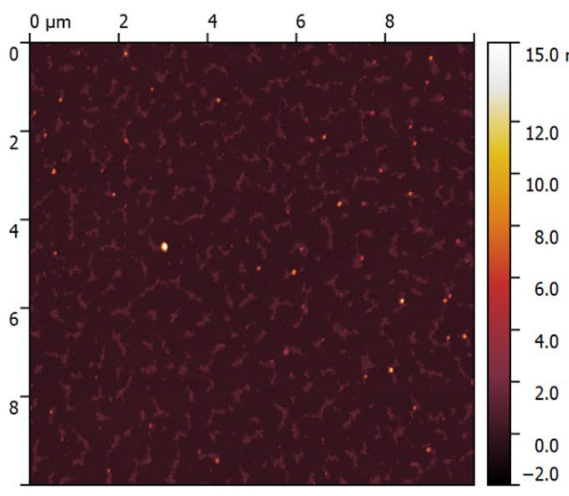

(A)

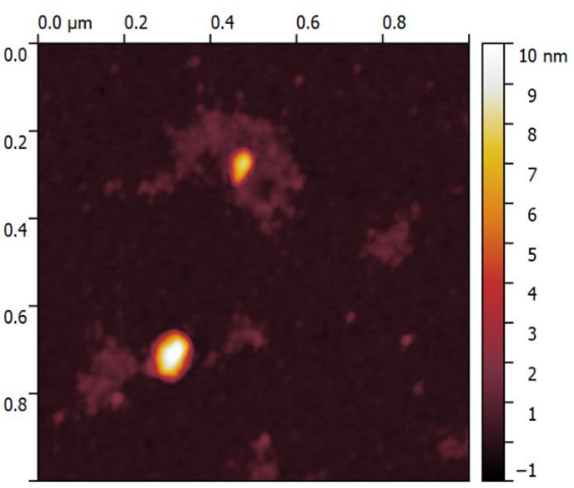

(B)

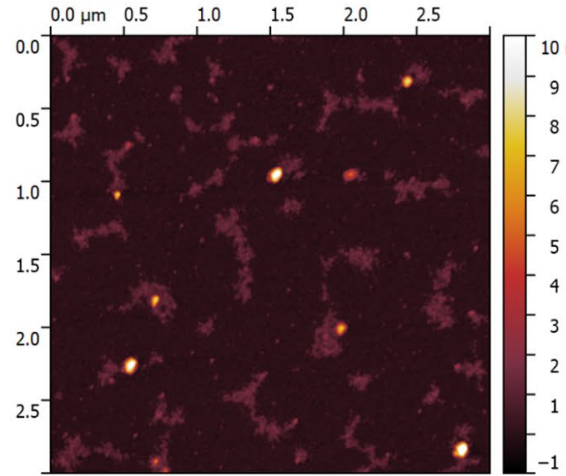

(C)

(E)

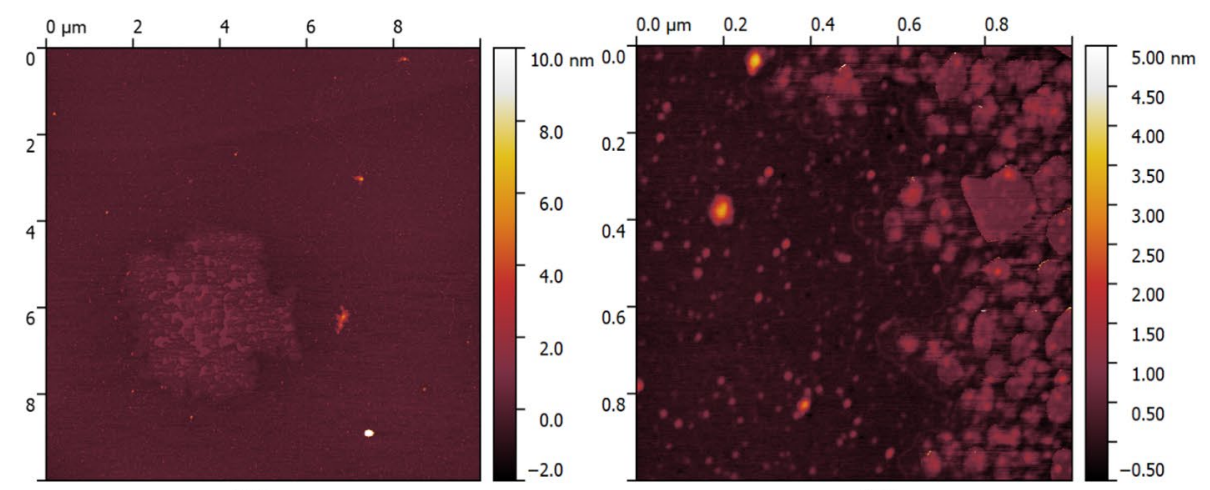

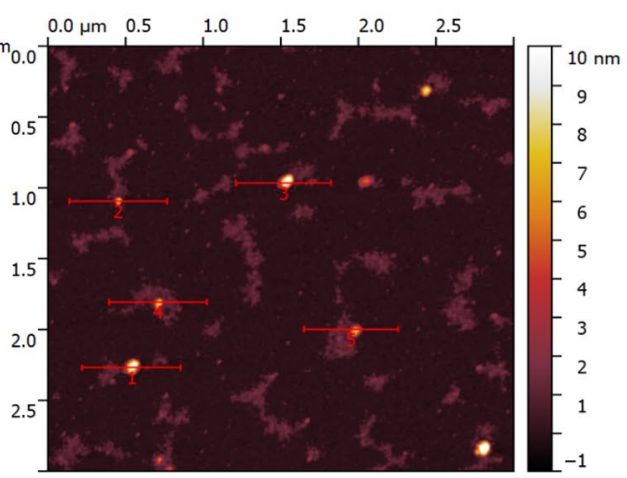

(D)

(F)

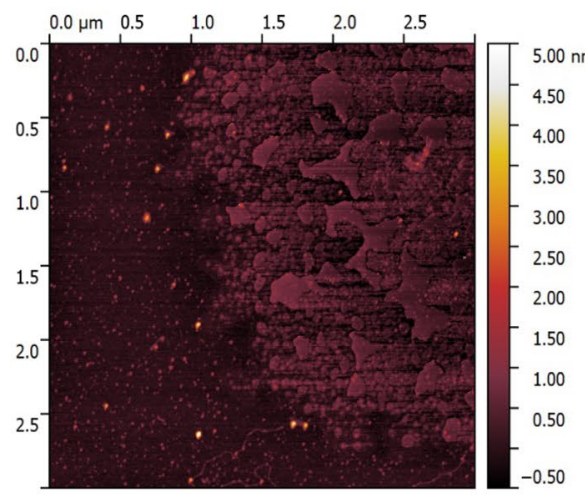

(G)

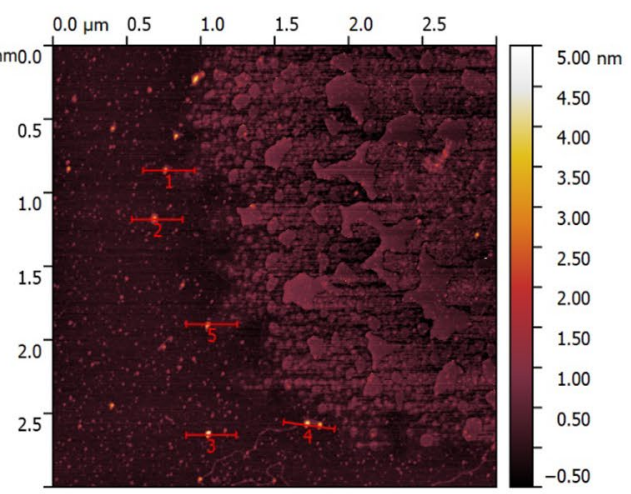

(H) 
constitutions. According to some studies, the phytotoxic properties of metal nanoparticles result from the production of ROS (reactive oxygen species), which causes oxidative stress, lipid peroxidation, and protein and DNA damage in plants. The literature shows that small nanoparticles $(<50 \mathrm{~nm})$ can penetrate and pass into the lymphatic system with ease. Then, they can access the vital organs and body tissues, and harm them. Nanoparticles of various sizes are absorbed by plants, transported to shoots and accumulated in aerial parts. As a result, there is a greater possibility of their circulation in the ecosystem through various trophic levels. Accumulated nanoparticles adversely affect crop quality. They lower the rate of seed germination, reduce biomass (both fresh and dry), and shorten roots and shoots. They also change photosynthesis, increase chromatin condensation, lead to a more extensive damage of DNA, decrease the rate of transpiration, increase lipid peroxidation, lead to the up- and down-regulation of various stress-related genes, and cause apoptosis. Plants have defense strategies that help them overcome the toxic effects of stress, including nanoparticles. To fight stress, plants can activate various defense systems of enzymatic and non-enzymatic nature. However, the inherent system responsible for detoxification does not combat toxicity beyond the limit of stress factors, which ultimately results in the apoptosis of plant cells.

The data on nanoparticle cytotoxicity to plants are still scarce. Plants are the basic part of all ecosystems and play a crucial role in the fates and transport of nanoparticles in the environment. They may also cause their bioaccumulation in the food chain. The influence of nanoparticles on the physiological processes in plants is very important to determine the safety of the applied materials. Phytotoxicity of any nanoparticle is largely influenced by its shape, size, chemical composition, and coating material composition. Further, phytotoxicity may depend on the environment and on the physical and chemical nature of the plant species. Nanoparticles may have potentiating or inhibitory effects on plant growth in different developmental stages. Some nanoparticles are taken up by plant roots and transported to the aboveground parts of the plant through the vascular system, depending on the composition, shape, size of nanoparticle, and anatomy of the plant [26].

There are no doubts that the method of producing metal nanoparticles impacts their toxicity. Studies carried out by Gopinath's research group [27] proved that the nanoparticles of pure $\mathrm{TiO}_{2}$, Au and $\mathrm{Pt}$ as well as doped $\mathrm{TiO}_{2}$ obtained from biological synthesis with the use of Terminalia arauna bark are not toxic. Shanthi et al. [28] obtained nanosilver using probiotic bacteria - Bacillus licheniformis. The authors observed that silver nanoparticles produced with the use of bacteria were less toxic to fresh crustaceans - Ceriodaphnia cornuta $(50 \mathrm{mg} / \mathrm{ml})$ than silver nitrate alone $(22 \mathrm{mg} / \mathrm{ml})$. Similar results were obtained by Zahir and Rahuman [29], who assessed the toxicity of nanosilver produced with the use of Euphorbia prostata leaf extract. The authors evaluated the toxic effect of particles and extracts made with the use of various solvents on Daphnia magna and Ceriodaphnia dubia. They observed no toxicity or side effects after exposure to the prepared extracts and the synthesized nanosilver. Similar results were obtained by Tripathi et al., who showed that $\mathrm{AgNO}_{3}$ is more toxic than a silver nanoparticle, while potential risks of both forms are critical to the growth and development of Cucumis sativus. According to the studies carried out by Tripathi et al., silver nanoparticles inhibit the growth and photosynthesis of Pisum sativum seedlings by enhancing oxidative stress and altering the antioxidant defense system. Also our previous studies [6] showed that nanosilver obtained as a result of synthesis with the use of Veronica officinalis extract stimulated the growth of garden cress and flax within the entire range of studied concentrations.

In this work, we have assessed the toxicity of $\mathrm{Au}$ and $\mathrm{Au} /$ $\mathrm{ZnO}$ nanoparticles, obtained with the use of $T$. parthenium extract, to 9 seeds of various plants: $L$. sativum, $L$. flavum, $Z$. mays, S. hispanica-chia, L. angustifolius, P. crispum subsp. Crispum, B. vulgaris, $P$. vulgaris. Figure 5 presents the photographs of the samples after the seed incubation period for: (A) beetroot $0.150 \mathrm{mg} / \mathrm{ml}$ Au nanoparticles; (B) chia $0.750 \mathrm{mg} / \mathrm{ml} \mathrm{Au} \mathrm{nanoparticles;} \mathrm{(C)} \mathrm{corn} \mathrm{0.3:3.0} \mathrm{mg/}$ $\mathrm{ml} \mathrm{Au/ZnO} \mathrm{nanoparticles;} \mathrm{(D)} \mathrm{bean} \mathrm{0.03:0.30} \mathrm{mg/ml} \mathrm{Au/}$ $\mathrm{ZnO}$ nanoparticles; (E) lupine 0.075:0.750 mg/ml Au/ZnO nanoparticles; (F) garden cress $0.003 \mathrm{mg} / \mathrm{ml}$ Au nanoparticles; (G) parsley feverfew extract $4.375 \mathrm{mg} / \mathrm{ml}$; (H) flax $0.075 \mathrm{mg} / \mathrm{ml}$ Au nanoparticles. Figure 6 shows the shoots of selected test plants exposed to the extract or solution of the tested nanoparticles.

The measured values of shoot growth or its inhibition, compared to the control sample, served as the basis for creating the charts showing the dependence of growth activity (Aw) \{100.(growth length of a respective seed - average length of the control sample)/average length of the control sample\} on concentration (C). The IC50 (i.e. the concentration at which the growth of the test plant was inhibited by 50\%) was calculated on the basis of the equation $\mathrm{Aw}=\mathrm{a} \cdot \mathrm{C}+\mathrm{b}$. The linear range of $\mathrm{A}(\mathrm{C})$ dependence was determined from the whole range of the studied concentrations on the basis of a logarithmic dependence $\mathrm{A}=\mathrm{a} \cdot \ln (\mathrm{C})+\mathrm{b}$. Figures 7,8 and 9 show the charts of shoot growth activity depending on the concentration of the extract, Au nanoparticles and $\mathrm{Au} / \mathrm{ZnO}$ nanoparticles for all test plants.

The equations, the square of correlation coefficient and the value of IC50 specified on the basis of experimental data are presented in Table 1. The wide range of the tested concentrations of feverfew extract, Au nanoparticles solution, and bimetallic $\mathrm{Au} / \mathrm{ZnO}$ nanoparticles solution made it 


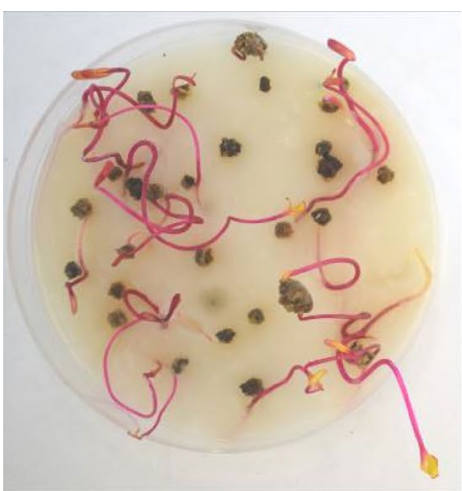

(A)

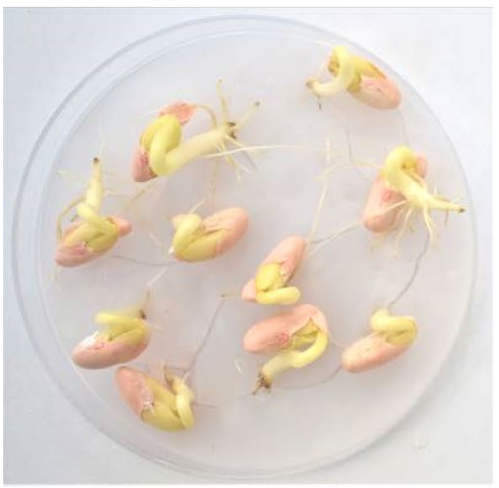

(D)

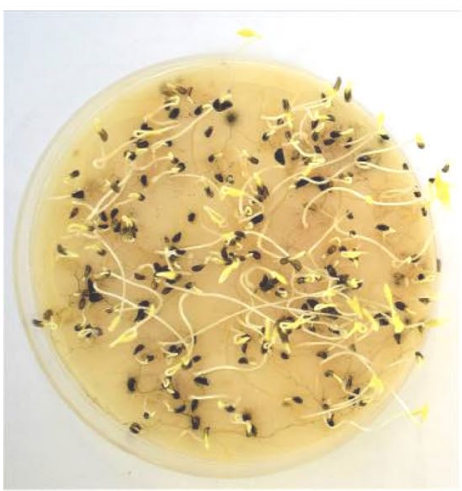

(G)

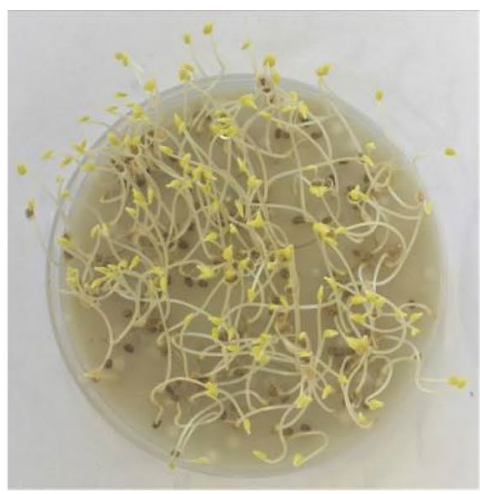

(B)

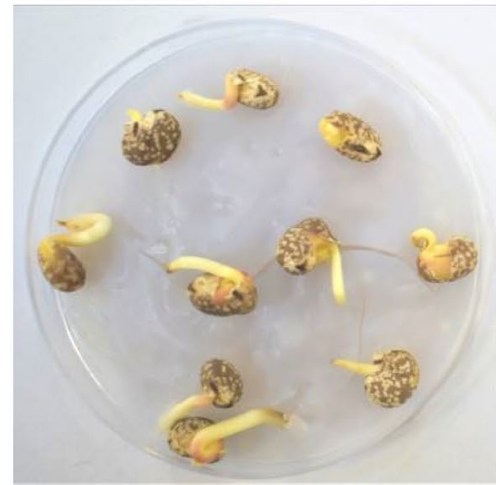

(E)

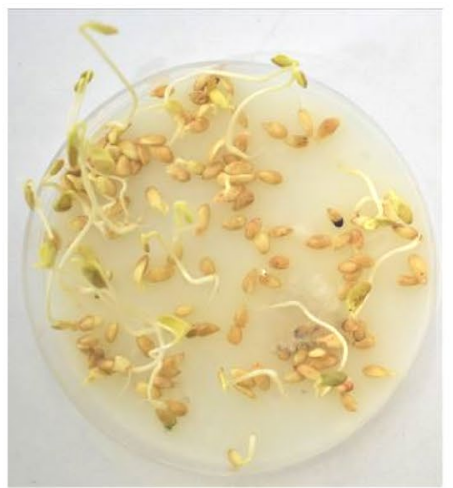

(H)

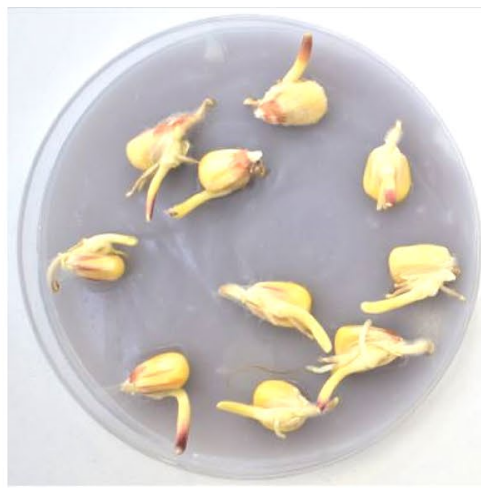

(C)

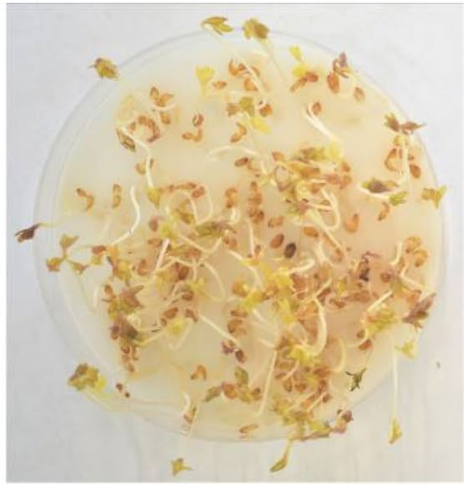

(F)
Fig. 5 Samples after the seed incubation period for: A beetroot $0.150 \mathrm{mg} / \mathrm{ml} \mathrm{Au}$ nanoparticles; B chia $0.750 \mathrm{mg} / \mathrm{ml} \mathrm{Au}$ nanoparticles; C corn 0.30:3.00 mg/ml $\mathrm{Au} / \mathrm{ZnO}$ nanoparticles; D bean 0.03:0.30 mg/ml Au/ZnO nanoparticles; E lupine 0.075:0.75 mg/ml

possible to observe changes in the selected plants that occur under the influence of a stress factor. The conducted studies showed that the feverfew extract was not toxic to corn, and it exhibited a high growth stimulating activity towards that plant in the entire range of tested concentrations. The solution was neutral to chia; only at the concentration of $10.5 \mathrm{mg} / \mathrm{ml}$ it was weakly toxic (average $\mathrm{Aw} \approx 9.8 \pm 2.2$ ).
$\mathrm{Au} / \mathrm{ZnO}$ nanoparticles; $\mathbf{F}$ garden cress $0.003 \mathrm{mg} / \mathrm{ml}$ Au nanoparticles; G parsley feverfew extract $4.375 \mathrm{mg} / \mathrm{ml} ; \mathbf{H}$ flax $0.075 \mathrm{mg} / \mathrm{ml}$ Au nanoparticles

Phytotoxicity as regards feverfew extract was exhibited by bean $($ IC50 $=9.10 \mathrm{mg} / \mathrm{ml}$ ) and beetroot (IC50 $=10.8 \mathrm{mg} / \mathrm{ml}$ ). It was the most toxic to lupine (IC50 $=1.8 \mathrm{mg} / \mathrm{ml}$ ).

$\mathrm{Au}$ nanoparticle solutions at a specific concentration range stimulated the growth of all the plants. The highest growth activity was exhibited by the solution at the concentration of $0.300 \mathrm{mg} / \mathrm{ml}$ as regards corn $(\mathrm{Aw} \approx-135 \pm 16)$ 


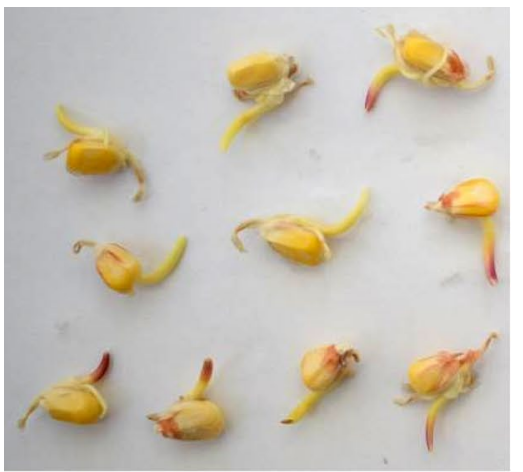

(A)

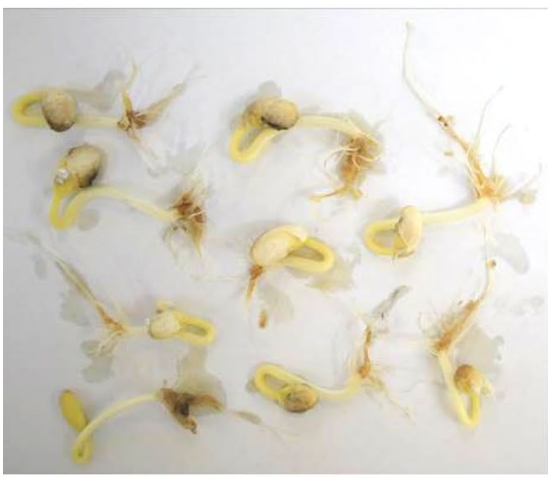

(D)

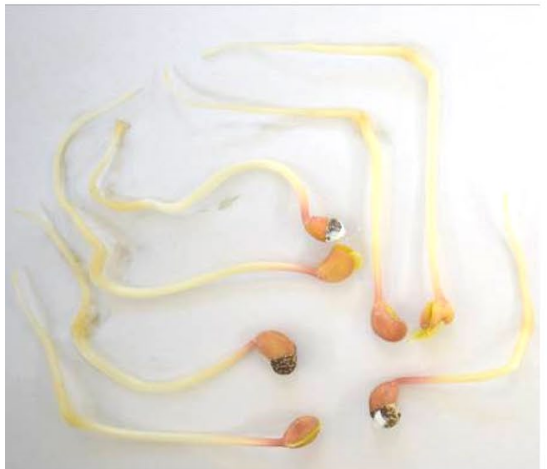

(G)

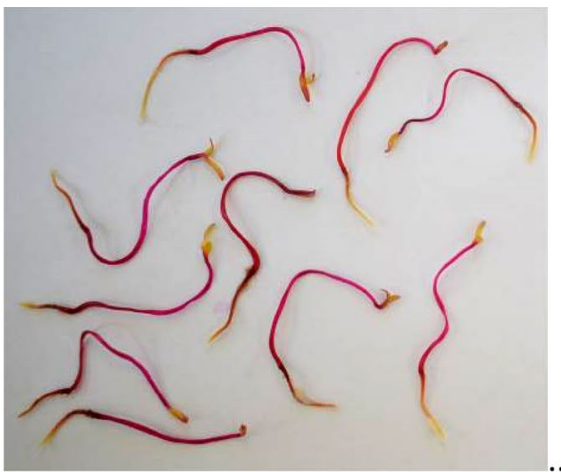

(B)

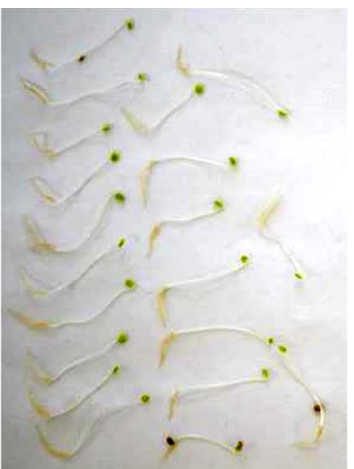

(C)

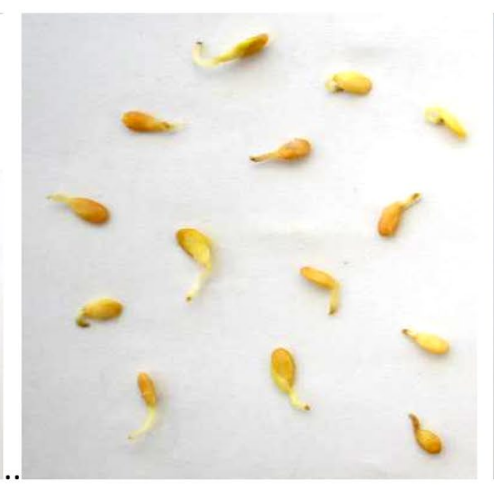

(E)

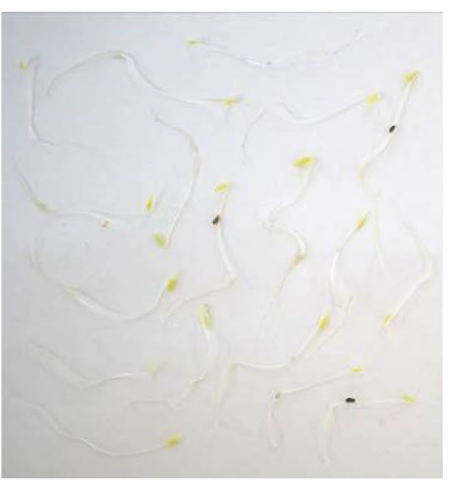

$(\mathrm{F})$

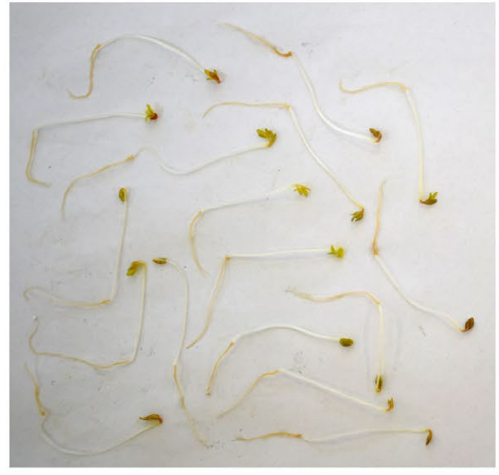

(H)

Fig. 6 Shoots of the selected test plants subjected to the extract or solution of the tested nanoparticles: A corn $0.30: 3,00 \mathrm{mg} / \mathrm{ml} \mathrm{Au} /$ $\mathrm{ZnO}$ nanoparticles; $\mathbf{B}$ beetroot $8.75 \mathrm{mg} / \mathrm{ml}$ feverfew extract; $\mathbf{C}$ chia $10.5 \mathrm{mg} / \mathrm{ml}$ feverfew extract; D bean $8.75 \mathrm{mg} / \mathrm{ml}$ feverfew; $\mathbf{E}$ flax

and flax $(\mathrm{Aw} \approx-44 \pm 10)$. Only for parsley the IC50 was successfully determined at $0.57 \mathrm{mg} / \mathrm{ml}$, but solutions at the concentration of 0.030 to $0.150 \mathrm{mg} / \mathrm{ml}$ also stimulated plant growth. $\mathrm{Au} / \mathrm{ZnO}$ nanoparticle solutions were toxic to all the plants. IC50 was from 0.0153:0.1530 mg/ml (for bean) to $0.243: 2.430 \mathrm{mg} / \mathrm{ml}$ for corn. The solution at the concentration of 0.01 and $0.10 \%$ stimulated the growth of $\operatorname{corn}[\operatorname{Aw}(0.01 \%) \approx-135 \pm 16],[\operatorname{Aw}(0.10 \%) \approx-73 \pm 12]$;
0.15:1,50 mg/ml Au/ZnO nanoparticles; F parsley $0.030 \mathrm{mg} / \mathrm{ml} \mathrm{Au}$ nanoparticles; G lupine blank sample; $\mathbf{H}$ garden cress $0.030 \mathrm{mg} / \mathrm{ml}$ Au nanoparticles

beetroot $[\operatorname{Aw}(0.01 \%) \approx-22 \pm 7],[\operatorname{Aw}(0.10 \%) \approx-17 \pm 5]$; garden cress $[\operatorname{Aw}(0.01 \%) \approx-13 \pm 4],[\operatorname{Aw}(0.10 \%) \approx$ $-2.9 \pm 3.5]$ and bean $[\operatorname{Aw}(0.01 \%) \approx-27 \pm 5]$, [Aw $(0.10 \%)$ $\approx-52 \pm 10]$. For the $0.01 \%$ concentration, the stimulating effect was observed for flax (Aw $\approx-1.7 \pm 2.6$ ); chia (Aw $\approx-8.5 \pm 4.2$ ); parsley $(\mathrm{Aw} \approx-10 \pm 5$ ).

The obtained test results indicated that the toxic activity is observed depending on the type and concentration 


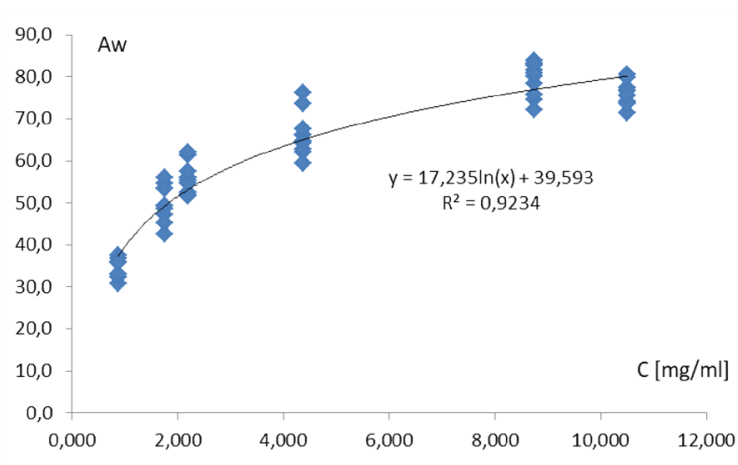

(A)

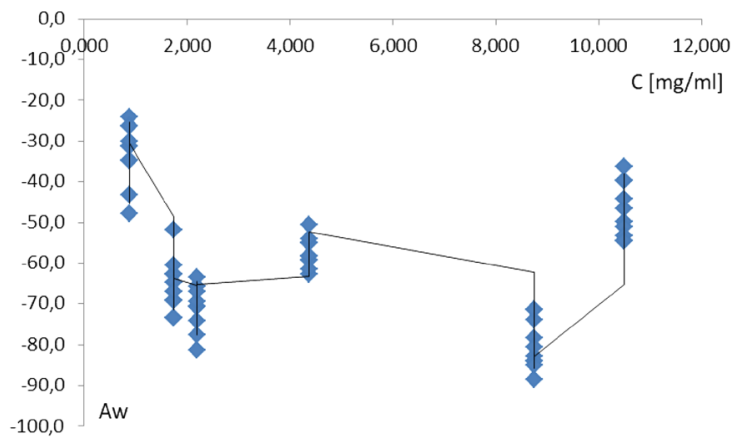

(C)

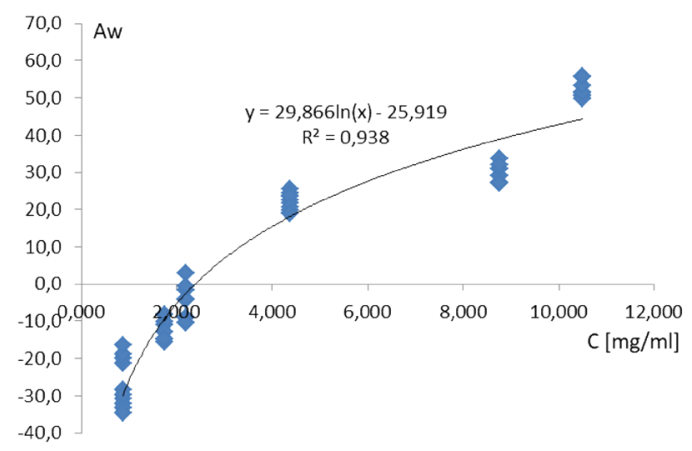

(E)

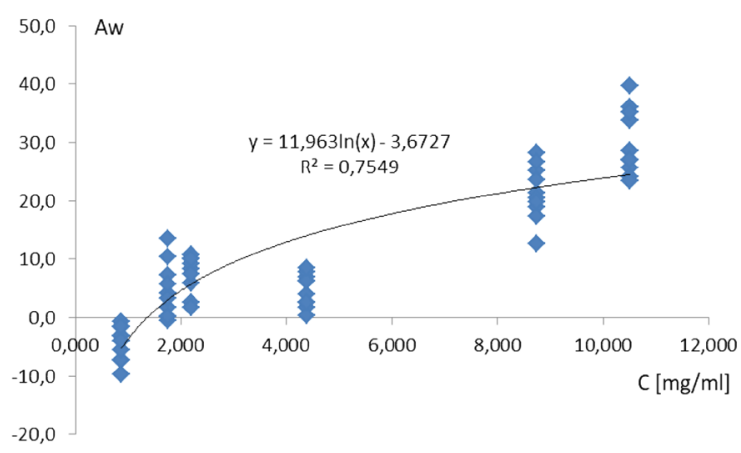

(G)

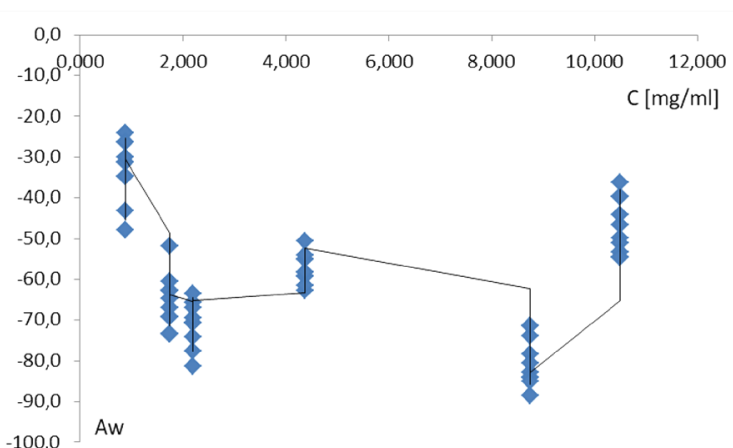

(B)

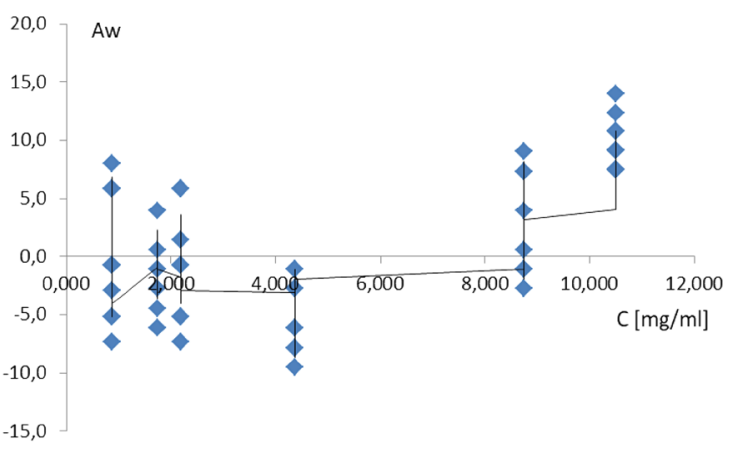

(D)

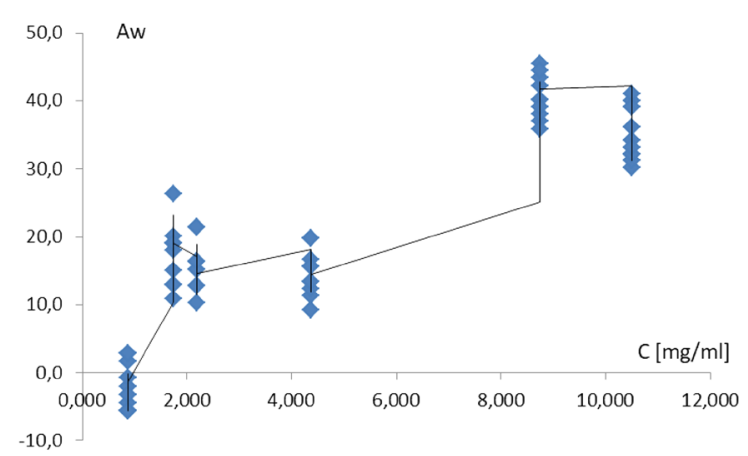

(F)

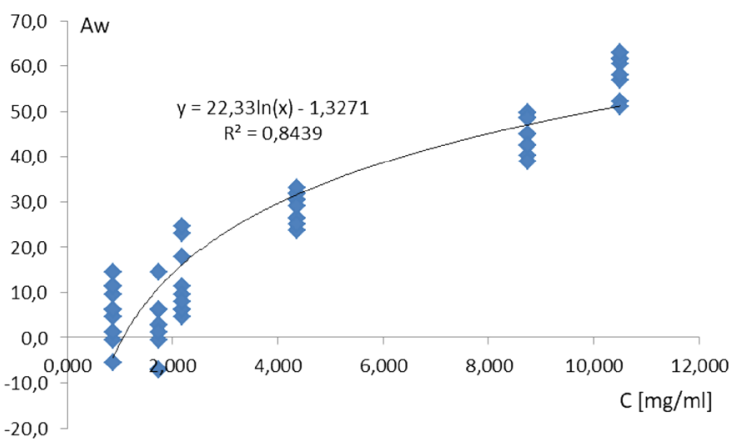

(H)

Fig. 7 Shoot growth activities of test plants depending on feverfew extract concentration: A lupine, $\mathbf{B}$ corn, $\mathbf{C}$ flax, $\mathbf{D}$ chia, $\mathbf{E}$ beetroot, $\mathbf{F}$ garden cress, $\mathbf{G}$ bean, $\mathbf{H}$ parsley 


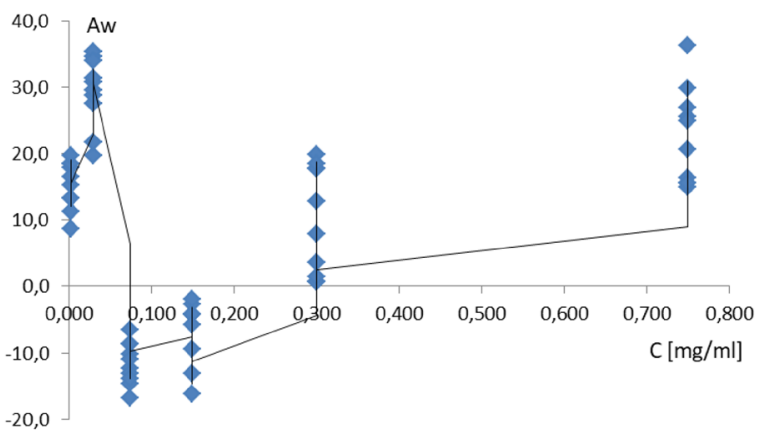

(A)

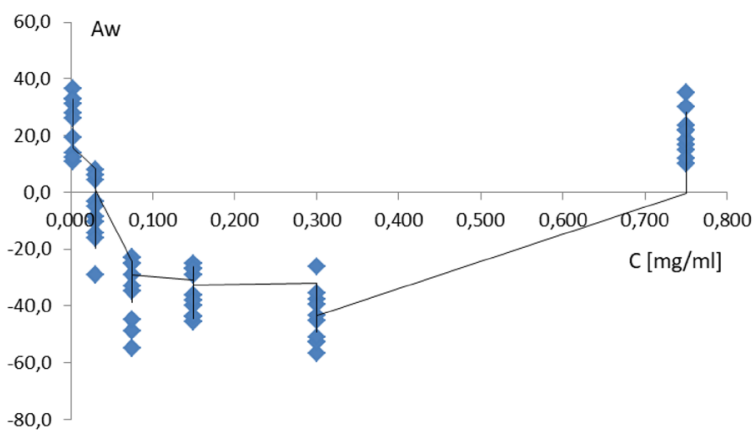

(C)

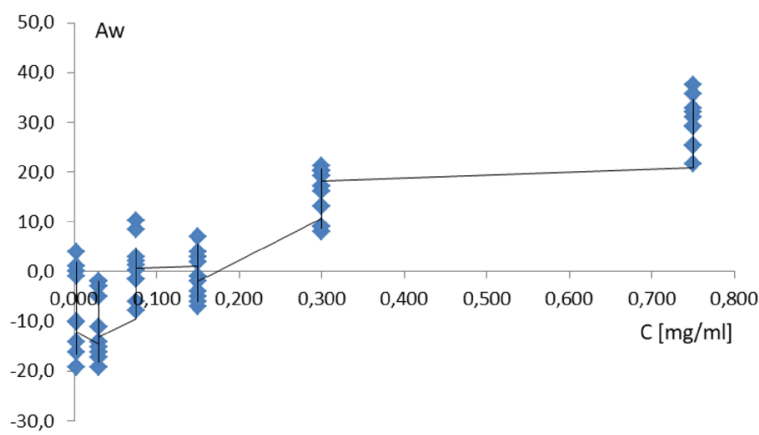

(E)

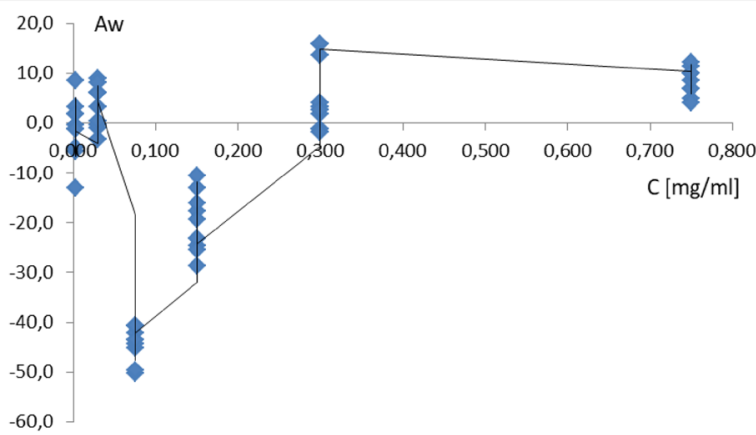

(G)

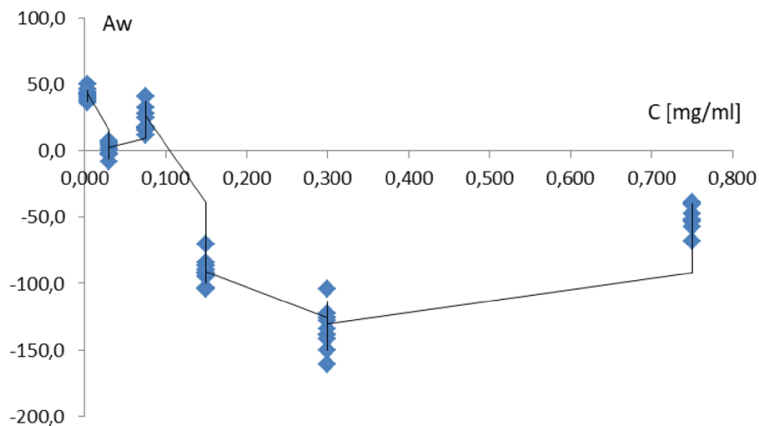

(B)

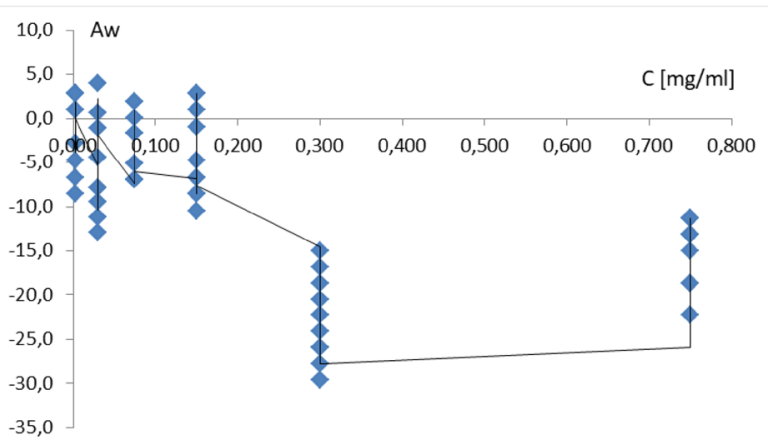

(D)

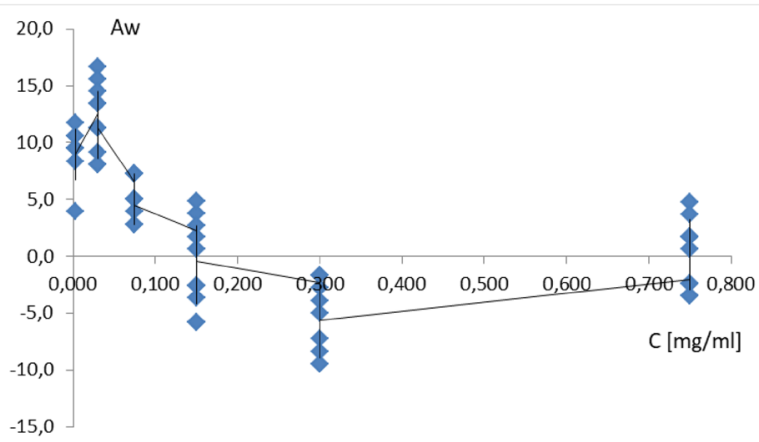

(F)

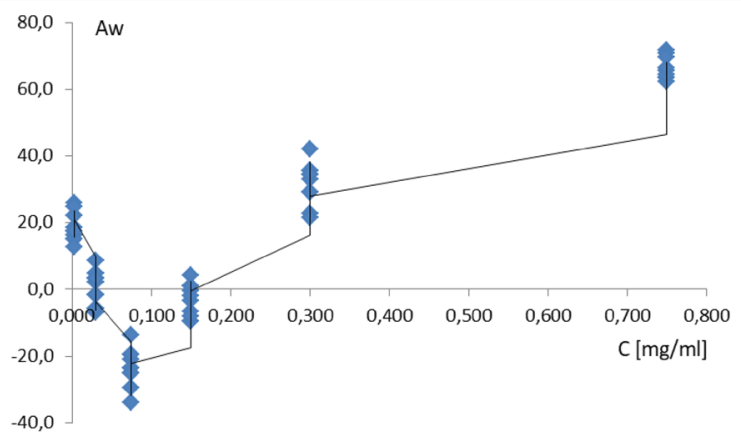

(H)

Fig. 8 Shoot growth activities of test plants depending on Au nanoparticle concentration: A lupine, $\mathbf{B}$ corn, $\mathbf{C}$ flax, D chia, $\mathbf{E}$ beetroot, $\mathbf{F}$ garden cress, $\mathbf{G}$ bean, $\mathbf{H}$ parsley 


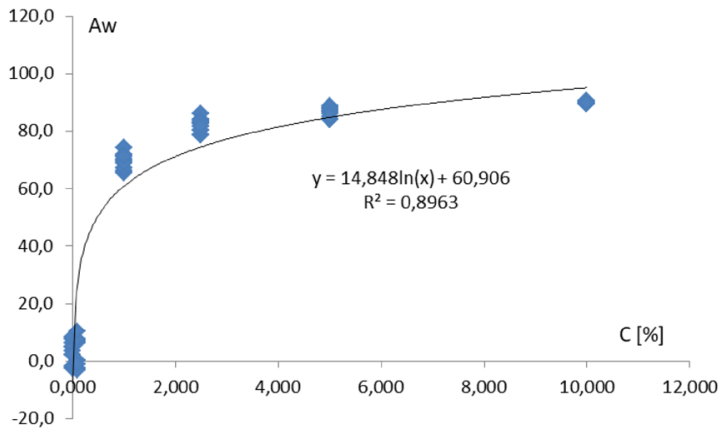

(A)

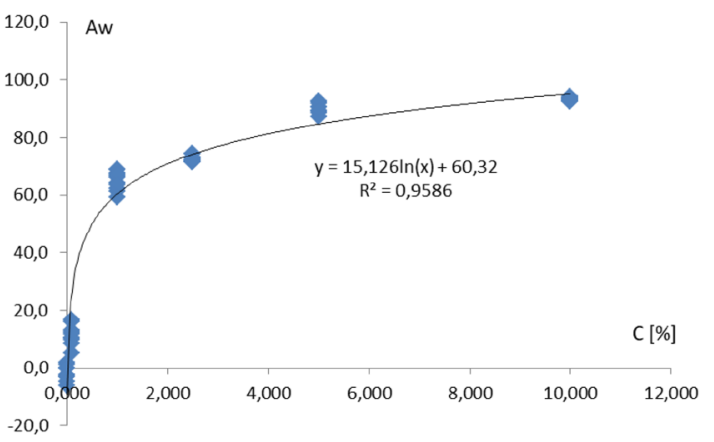

(C)

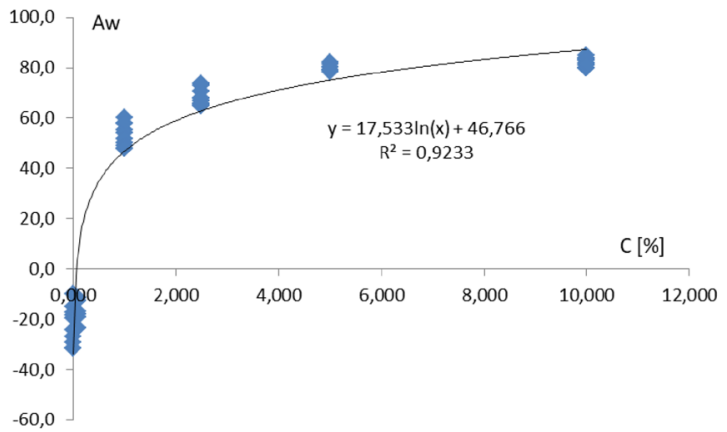

(E)

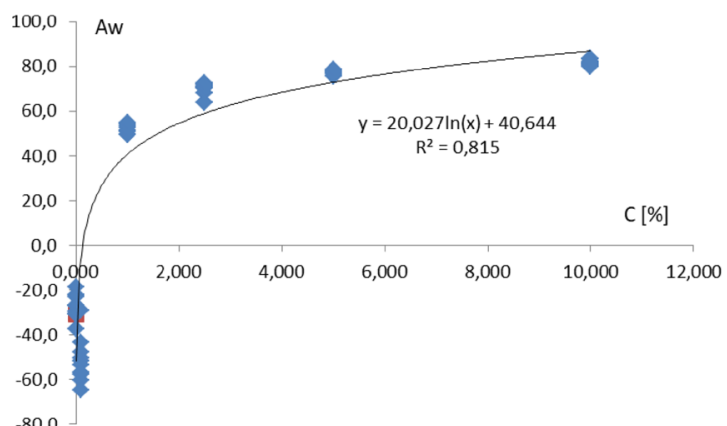

(G)

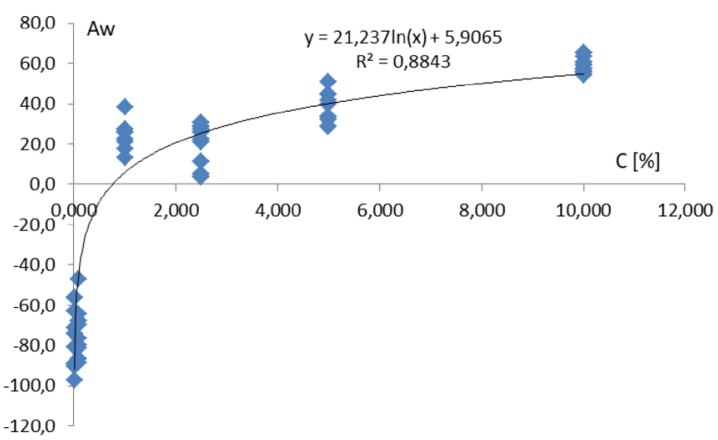

(B)

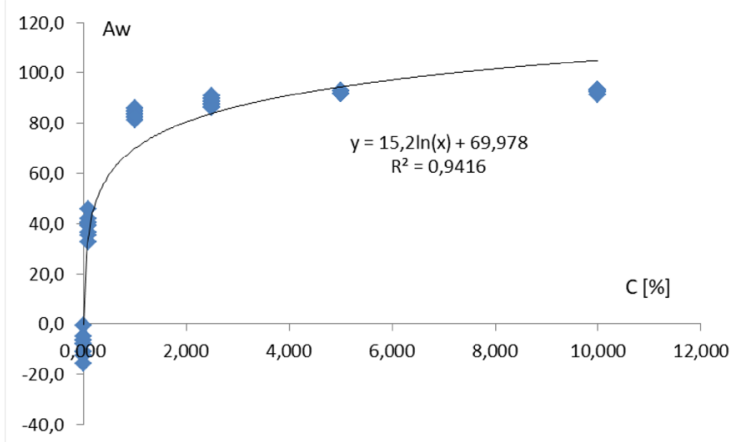

(D)

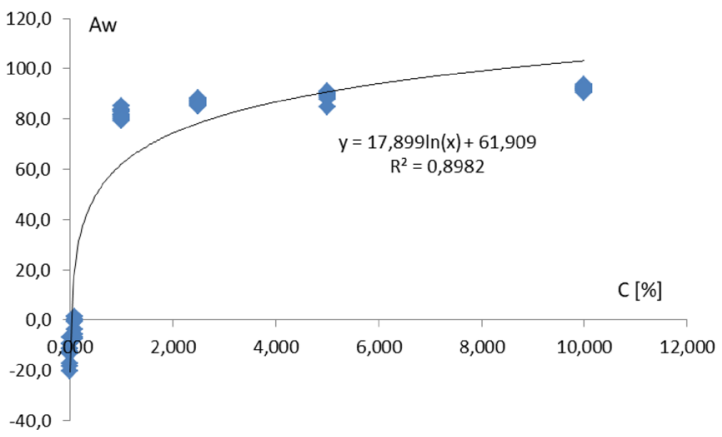

(F)

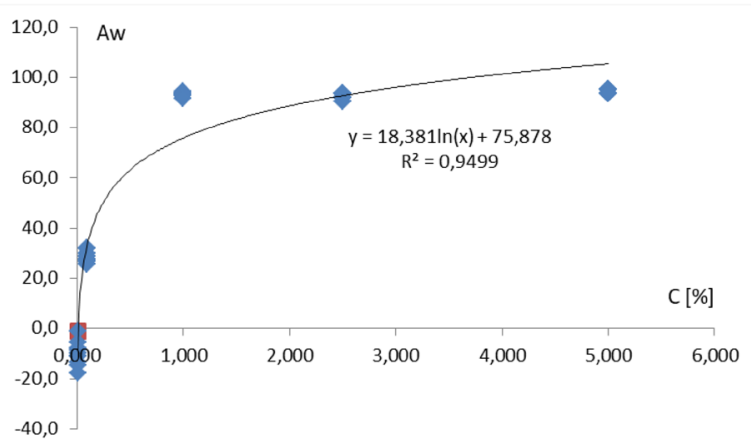

(H)

Fig. 9 Shoot growth activities of test plants depending on Au/ZnO nanoparticle concentration: A lupine, $\mathbf{B}$ corn, $\mathbf{C}$ flax, $\mathbf{D}$ chia, $\mathbf{E}$ beetroot, $\mathbf{F}$ garden cress, $\mathbf{G}$ bean, $\mathbf{H}$ parsley 
Table 1 The identified $\mathrm{IC}_{50}$ parameters, curve equations and correlation parameters

\begin{tabular}{|c|c|c|c|}
\hline & Tanacetum parthenium extract & $\begin{array}{l}\text { Biosynthesized } \\
\mathrm{Au} \\
\text { Nanoparticles }\end{array}$ & $\begin{array}{l}\text { Biosynthesized } \\
\mathrm{Au} / \mathrm{ZnO} \text { nanoparticles }\end{array}$ \\
\hline Range of tested concentrations & $0,875-10,5 \mathrm{mg} / \mathrm{ml}$ & $0,003-0,750 \mathrm{mg} / \mathrm{ml}$ & $0,010-10,0 \%$ \\
\hline Equation $\mathrm{A}=\mathrm{a} * \ln (\mathrm{C})+\mathrm{b}$ & $\mathrm{A}=17,235 \ln (\mathrm{C})+39,593$ & n.d & $A=14,848 \ln (C)+60,906$ \\
\hline Correlation coefficient $\mathrm{R}^{2}$ & 0,9234 & - & 0,8963 \\
\hline Linear section equation $\mathrm{A}=\mathrm{C}^{*} \mathrm{a}+\mathrm{b}$ & $A=15,998 C+21,019$ & n.d & $A=69,562 C-0.2184$ \\
\hline Correlation coefficient $\mathrm{R}^{2}$ & 0,8622 & - & 0,9790 \\
\hline $\mathrm{IC}_{50}$ for Lupinus angustifolius $[\mathrm{mg} / \mathrm{ml}]$ & 1,8 & n.d & $0.0216: 0.216$ \\
\hline Range of tested concentrations & $0,875-10,5 \mathrm{mg} / \mathrm{ml}$ & $0,003-0,750 \mathrm{mg} / \mathrm{ml}$ & $0,010-10,0 \%$ \\
\hline Equation $\mathrm{A}=\mathrm{a} * \ln (\mathrm{C})+\mathrm{b}$ & n.d.* & n.d & $\mathrm{A}=21,237 \ln (\mathrm{C})+5,9065$ \\
\hline Correlation coefficient $\mathrm{R}^{2}$ & - & - & 0,8843 \\
\hline Linear section equation $\mathrm{A}=\mathrm{C}^{*} \mathrm{a}+\mathrm{b}$ & n.d & n.d & $\mathrm{A}=4,9464 \mathrm{C}+10,119$ \\
\hline Correlation coefficient $\mathrm{R}^{2}$ & - & - & 0,8085 \\
\hline $\mathrm{IC}_{50}$ for Zea mays $[\mathrm{mg} / \mathrm{ml}]$ & n.d & n.d & $0.243: 2.430$ \\
\hline Range of tested concentrations & $0,875-10,5 \mathrm{mg} / \mathrm{ml}$ & $0,003-0,750 \mathrm{mg} / \mathrm{ml}$ & $0,010-10,0 \%$ \\
\hline Equation $\mathrm{A}=\mathrm{a} * \ln (\mathrm{C})+\mathrm{b}$ & n.d & n.d & $A=15,126 \ln (C)+60,32$ \\
\hline Correlation coefficient $\mathrm{R}^{2}$ & - & - & 0,9586 \\
\hline Linear section equation $\mathrm{A}=\mathrm{C}^{*} \mathrm{a}+\mathrm{b}$ & n.d & n.d & $A=63,979 C+1,1864$ \\
\hline Correlation coefficient $\mathrm{R}^{2}$ & - & - & 0,9786 \\
\hline $\mathrm{IC}_{50}$ for Linum flavum $[\mathrm{mg} / \mathrm{ml}]$ & n.d & n.d & 0.0228:0.228 \\
\hline Range of tested concentrations & $0,875-10,5 \mathrm{mg} / \mathrm{ml}$ & $0,003-0,750 \mathrm{mg} / \mathrm{ml}$ & $0,010-10,0 \%$ \\
\hline Equation $\mathrm{A}=\mathrm{a} * \ln (\mathrm{C})+\mathrm{b}$ & n.d & n.d & $A=15,2 \ln (C)+69,978$ \\
\hline Correlation coefficient $\mathrm{R}^{2}$ & - & - & 0,9416 \\
\hline Linear section equation $\mathrm{A}=\mathrm{C}^{*} \mathrm{a}+\mathrm{b}$ & n.d & n.d & $A=75,291 C+10,519$ \\
\hline Correlation coefficient $\mathrm{R}^{2}$ & - & - & 0,7910 \\
\hline $\mathrm{IC}_{50}$ for Salvia hispanica $[\mathrm{mg} / \mathrm{ml}]$ & n.d & n.d & $0.0156: 0.156$ \\
\hline Range of tested concentrations & $0,875-10,5 \mathrm{mg} / \mathrm{ml}$ & $0,003-0,750 \mathrm{mg} / \mathrm{ml}$ & $0,010-10,0 \%$ \\
\hline Equation $\mathrm{A}=\mathrm{a} * \ln (\mathrm{C})+\mathrm{b}$ & $A=29,866 \ln (C)-25,919$ & n.d & $A=17,533 \ln (C)+46,766$ \\
\hline Correlation coefficient $\mathrm{R}^{2}$ & 0,938 & - & 0,9233 \\
\hline Linear section equation $\mathrm{A}=\mathrm{C}^{*} \mathrm{a}+\mathrm{b}$ & $A=5,7927 C-12,691$ & n.d & $A=36,748 C-12,59$ \\
\hline Correlation coefficient $\mathrm{R}^{2}$ & 0,8633 & - & 0,8149 \\
\hline $\mathrm{IC}_{50}$ for Beta vulgaris $[\mathrm{mg} / \mathrm{ml}]$ & 10,8 & n.d & 0.051:0.510 \\
\hline Range of tested concentrations & $0,875-10,5 \mathrm{mg} / \mathrm{ml}$ & $0,003-0,750 \mathrm{mg} / \mathrm{ml}$ & $0,010-10,0 \%$ \\
\hline Equation $\mathrm{A}=\mathrm{a} * \ln (\mathrm{C})+\mathrm{b}$ & $\mathrm{A}=14,553 \ln (\mathrm{C})+2,7482$ & n.d & $A=17,899 \ln (C)+61,909$ \\
\hline Correlation coefficient $\mathrm{R}^{2}$ & 0,7924 & - & 0,8982 \\
\hline Linear section equation $\mathrm{A}=\mathrm{C} * \mathrm{a}+\mathrm{b}$ & n.d & n.d & $A=95,533 C-13,283$ \\
\hline Correlation coefficient $\mathrm{R}^{2}$ & - & - & 0,9941 \\
\hline $\mathrm{IC}_{50}$ for Lepidium sativum $[\mathrm{mg} / \mathrm{ml}]$ & n.d & n.d & 0.0198:0.198 \\
\hline Range of tested concentrations & $0,875-10,5 \mathrm{mg} / \mathrm{ml}$ & $0,003-0,750 \mathrm{mg} / \mathrm{ml}$ & $0,010-10,0 \%$ \\
\hline Equation $\mathrm{A}=\mathrm{a} * \ln (\mathrm{C})+\mathrm{b}$ & $A=11,963 \ln (C)-3,6727$ & n.d & $\mathrm{A}=20,027 \ln (\mathrm{C})+40,644$ \\
\hline Correlation coefficient $\mathrm{R}^{2}$ & 0,7549 & - & 0,815 \\
\hline Linear section equation $\mathrm{A}=\mathrm{C} * \mathrm{a}+\mathrm{b}$ & n.d & n.d & $A=46,769 C-32,535$ \\
\hline Correlation coefficient $\mathrm{R}^{2}$ & - & - & 0,736 \\
\hline $\mathrm{IC}_{50}$ for Phaseolus vulgaris $[\mathrm{mg} / \mathrm{ml}]$ & n.d & n.d & 0.0540:0,540 \\
\hline Range of tested concentrations & $0,875-10,5 \mathrm{mg} / \mathrm{ml}$ & $0,003-0,750 \mathrm{mg} / \mathrm{ml}$ & $0,010-10,0 \%$ \\
\hline Equation $\mathrm{A}=\mathrm{a} * \ln (\mathrm{C})+\mathrm{b}$ & $A=22,33 \ln (C)-1,3271$ & n.d & $\mathrm{A}=18,381 \ln (\mathrm{C})+75,878$ \\
\hline Correlation coefficient $\mathrm{R}^{2}$ & 0,8439 & - & 0,9499 \\
\hline Linear section equation $\mathrm{A}=\mathrm{C}^{*} \mathrm{a}+\mathrm{b}$ & $\mathrm{A}=5,801 \mathrm{C}-2,5678$ & $A=107,24 C-11,316$ & $A=91,002 C+3,5175$ \\
\hline Correlation coefficient $\mathrm{R}^{2}$ & 0,9117 & 0,8967 & 0,9098 \\
\hline
\end{tabular}


Table 1 (continued)

\begin{tabular}{llll}
\hline & Tanacetum parthenium extract & $\begin{array}{l}\text { Biosynthesized } \\
\text { Au } \\
\text { Nanoparticles }\end{array}$ & $\begin{array}{l}\text { Biosynthesized } \\
\text { Au/ZnO nanoparticles }\end{array}$ \\
\hline $\begin{array}{l}\mathrm{C}_{50} \text { for Petroselinum crispum subsp. crispum } \\
{[\mathrm{mg} / \mathrm{ml}]}\end{array}$ & 9,10 & 0,57 & $0.0153: 0.153$ \\
\hline
\end{tabular}

*n.d. not designated

of nanoparticles. Our studies showed that gold nanoparticle solutions stimulated the growth of tested plants at a wide range of concentrations. Similar studies were carried out by Ndeh et al. [30]. They showed that biologically synthesized gold nanoparticles were of minimal toxicity to rice seedlings. Increases in cell death, hydrogen peroxide formation and lipid peroxidation in roots and shoots were noted. However, these increases were not statistically significant. A dose-dependent increase in absorbance was observed with increasing concentrations of gold nanoparticle treatments. This indicated that cell mortality increases with rising concentrations of the nanoparticles. However, the extent of cell death was not enough for a threat to significantly stunt plant growth.

As regards $\mathrm{Au} / \mathrm{ZnO}$ bimetallic nanoparticles, along with the increase there was observed a toxic effect on the tested plants. Therefore, the addition of $\mathrm{ZnO}$ nanoparticles is significant, as it has proven to exhibit toxic activity at higher concentrations. Low concentrations of $\mathrm{ZnO}$ nanoparticles are beneficial to plants. Positive effects of $\mathrm{ZnO}$ nanoparticles are manifested in promoting germination, stem and root growth, increase in phosphorus mobilizing enzymes, phosphorus uptake, and antifungal properties [26]. Although $\mathrm{Zn}$ is crucial for sustaining the biological activity of numerous proteins, it causes toxicity when accumulated in excess due to its episodic binding to proteins and consequential displacement of other metal ions including $\mathrm{Fe}$ [31]. The toxicity of $\mathrm{ZnO}$ nanoparticles was also shown by Chen et al. [32], who reported dosedependent phytotoxicity of $\mathrm{ZnO}$ nanoparticles to rice seedlings. They documented a marked reduction in root length, shoot height, and biomass, especially with $\mathrm{ZnO}$ nanoparticles at concentrations higher than $250 \mathrm{mg} / \mathrm{L}$. Also Lin and Xing [33] documented a retardation in seedling growth and shorter roots and shoots than the control in ryegrass treated with $\mathrm{ZnO}$ nanoparticles, especially at concentrations of $\mathrm{ZnO}$ nanoparticles higher than $50 \mathrm{mg} / \mathrm{L}$. Wang et al. [34] also confirmed that a high dose of $\mathrm{ZnO}$ nanoparticles can release bioavailable $\mathrm{Zn}^{2+}$ and produce significant toxicity to plants.

\section{Conclusion}

The increased production of metal nanoparticles and their broad use contribute to their spread in the environment. According to the published data, they are stable in water, highly reactive, and their small sizes allow for a fast penetration into tissues and organs. In consequence, they can cause negative effects in land and water organisms. It is necessary to conduct extensive ecotoxicological studies of metal nanoparticles in order to predict their negative effects on the environment. This work is an answer to that need. In this work, we have assessed the toxicity of $\mathrm{Au}$ and $\mathrm{Au} / \mathrm{ZnO}$ metal nanoparticles obtained from biological synthesis with the use of T. parthenium extract. The nanoparticles were characterized by UV-VIS, TEM, AFM, and FTIR. In the assessment, we used the following seeds: L. sativum, L. flavum, Z. mays, $S$. hispanica-chia, L. angustifolius, P. crispum subsp. Crispum, $B$. vulgaris, $P$. vulgaris. The in vitro phytotests showed that gold nanoparticles at a specific range of concentrations for all plants stimulated their growth. Bimetallic $\mathrm{Au} / \mathrm{ZnO}$ nanoparticle solutions, except at the lowest concentrations, had a toxic effect on all test plants. Of all tested plants, the most sensitive one to the tested nanoparticle solutions was parsley. Corn was the most resilient to $\mathrm{Au}$ and $\mathrm{Au} / \mathrm{ZnO}$ nanoparticle solutions.

\section{Declarations}

Conflict of interest The authors declare that they have no conflict of interest.

Open Access This article is licensed under a Creative Commons Attribution 4.0 International License, which permits use, sharing, adaptation, distribution and reproduction in any medium or format, as long as you give appropriate credit to the original author(s) and the source, provide a link to the Creative Commons licence, and indicate if changes were made. The images or other third party material in this article are included in the article's Creative Commons licence, unless indicated otherwise in a credit line to the material. If material is not included in the article's Creative Commons licence and your intended use is not permitted by statutory regulation or exceeds the permitted use, you will need to obtain permission directly from the copyright holder. To view a copy of this licence, visit http://creativecommons.org/licenses/by/4.0/. 


\section{References}

1. S. Faisal, H. Jan, S.A. Shah, S. Shah, A. Khan, M.T. Akbar, M. Rizwan, F. Jan, A.N. Wajidullah, A. Khattak, S. Syed, Green synthesis of zinc oxide ( $\mathrm{ZnO}$ ) nanoparticles using aqueous fruit extracts of Myristica fragrans: their characterizations and biological and environmental applications. ACS Omega 6(14), 9709-9722 (2021)

2. N. Rabiee, M.T. Yaraki, S.M. Garakani, S.M. Garakani, S. Ahmadi, A. Lajevardi, M. Bagherzadeh, M. Rabiee, L. Tayebi, M. Tahriri, M.R. Hamblin, Recent advances in porphyrin-based nanocomposites for effective targeted imaging and therapy. Biomaterials 232, 119707 (2020)

3. W. Zhu, C. Hu, Y. Ren, Y. Lu, Y. Song, Y. Ji, C. Han, J. He, Green synthesis of zinc oxide nanoparticles using Cinnamomum camphora (L.) Presl leaf extracts and its antifungal activity. J. Environ. Chem. Eng. (2021). https://doi.org/10.1016/j.jece.2021.106659

4. F. Ameen, K. Alsamhary, J.A. Alabdullatif, S. ALNadhari, A review on metal-based nanoparticles and their toxicity to beneficial soil bacteria and fungi. Ecotoxicol. Environ. Saf.213, 112027 (2021)

5. M. Gupta, R.S. Tomar, S. Kaushik, R.K. Mishra, D. Sharma, Effective antimicrobial activity of green $\mathrm{ZnO}$ nano particles of Catharanthus roseus. Front. Microbiol. 9, 2030 (2018)

6. R. Dobrucka, M. Szymanski, R. Przekop, The study of toxicity effects of biosynthesized silver nanoparticles using Veronica officinalis extract. Int. J. Environ. Sci. Technol. 16(12), 8517-8526 (2019)

7. P. Khandel, R.K. Yadaw, D.K. Soni, L. Kanwar, S.K. Shahi, Biogenesis of metal nanoparticles and their pharmacological applications: present status and application prospects. J. Nanostruct. Chem. 8(3), 217-254 (2018)

8. N. Shreyash, S. Bajpai, M.A. Khan, Y. Vijay, S. K. Tiwary, M. Sonker, Green synthesis of nanoparticles and their biomedical applications: a review. ACS Applied Nano Materials. 4(11), 11428-11457 (2021)

9. A. Loosen, C. Simms, S. Smolders, D.E. De Vos, T.N. Parac-Vogt, Bimetallic Ce/Zr UiO-66 metal-organic framework nanostructures as peptidase and oxidase nanozymes. ACS Applied Nano Materials (2021)

10. R. Rajan, K. Chandran, S.L. Harper, S.I. Yun, P.T. Kalaichelvan, Plant extract synthesized silver nanoparticles: an ongoing source of novel biocompatible materials. Ind. Crops Prod. 70, 356-373 (2015)

11. M.A. Abomuti, E.Y. Danish, A. Firoz, N. Hasan, M.A. Malik, Green Synthesis of Zinc Oxide Nanoparticles Using Salvia officinalis Leaf Extract and Their Photocatalytic and Antifungal Activities. Biology 10(11), 1075 (2021)

12. H. Jan, M. Shah, A. Andleeb, S. Faisal, A. Khattak, M. Rizwan, S. Drouet, C. Hano, B.H. Abbasi, Plant-based synthesis of zinc oxide nanoparticles (ZnO-NPs) using aqueous leaf extract of aquilegia pubiflora: their antiproliferative activity against HepG2 cells inducing reactive oxygen species and other in vitro properties. Oxidative medicine and cellular longevity (2021)

13. A. Umamaheswari, S.L. Prabu, S.A. John, A. Puratchikody, Green synthesis of zinc oxide nanoparticles using leaf extracts of Raphanus sativus var. Longipinnatus and evaluation of their anticancer property in A549 cell lines. Biotechnol. Rep. 29, e00595 (2021)

14. A. Milewska-Hendel, M. Zubko, J. Karcz, D. Stróż, E. Kurczyńska, Fate of neutral-charged gold nanoparticles in the roots of the Hordeum vulgare L. cultivar Karat. Sci. Rep. 7(1), $1-13(2017)$
15. M. Szymanski, R. Dobrucka, Evaluation of phytotoxicity of bimetallic Ag/Au nanoparticles synthesized using Geum urbanum L. J. Inorg. Organomet. Polym. Mater. 31(6), 2459-2470 (2021)

16. L' Balážová, P. Babula, M. Baláž, M. Bačkorová, Z. Bujňáková, J. Briančin, A. Kurmanbayeva, M. Sagi, Zinc oxide nanoparticles phytotoxicity on halophyte from genus Salicornia. Plant Physiol. Biochem. 130, 30-42 (2018)

17. S. Bousalem, F.Z. Zeggai, H. Baltach, A. Benyoucef, Physical and electrochemical investigations on hybrid materials synthesized by polyaniline with various amounts of $\mathrm{ZnO}$ nanoparticle. Chem. Phys. Lett. 741, 137095 (2020)

18. W. Muhammad, N. Ullah, M. Haroon, B.H. Abbasi, Optical, morphological and biological analysis of zinc oxide nanoparticles (ZnO NPs) using Papaver somniferum L. RSC Adv. 9(51), 29541-29548 (2019)

19. A. Stojakowska, W. Kisiel, Metabolity wtórne korzeni wiośnikowatych Tanacetum parthenium. Biotechnologia 3(62), 87-94 (2003)

20. K. Végh, E. Riethmüller, L. Hosszú, A. Darcsi, J. Müller, Á. Alberti, A. Tóth, S. Béni, Á. Könczöl, G.T. Balogh, Á. Kéry, Three newly identified lipophilic flavonoids in Tanacetum parthenium supercritical fluid extract penetrating the Blood-Brain Barrier. J. Pharm. Biomed. Anal. 149, 488-493 (2018)

21. C. Wu, F. Chen, X. Wang, H.J. Kim, G.Q. He, V. Haley-Zitlin, G. Huang, Antioxidant constituents in feverfew (Tanacetum parthenium) extract and their chromatographic quantification. Food Chem. 96(2), 220-227 (2006)

22. C. Wu, F. Chen, X. Wang, Y. Wu, M. Dong, G. He, R.D. Galyean, L. He, G. Huang, Identification of antioxidant phenolic compounds in feverfew (Tanacetum parthenium) by HPLC-ESI-MS/ MS and NMR. Phytochem. Anal. 18(5), 401-410 (2007)

23. K. Martin, R. Sur, F. Liebel, N. Tierney, P. Lyte, M. Garay, T. Oddos, M. Anthonavage, S. Shapiro, M. Southall, Parthenolidedepleted feverfew (Tanacetum parthenium) protects skin from UV irradiation and external aggression. Arch. Dermatol. Res. 300(2), 69-80 (2008)

24. C.J. O'Conor, H.A. Leddy, H.C. Benefield, W.B. Liedtke, F. Guilak, TRPV4-mediated mechanotransduction regulates the metabolic response of chondrocytes to dynamic loading. Proc. Natl. Acad. Sci. 111(4), 1316-1321 (2014)

25. K.M. Perrott, C.D. Wiley, P.Y. Desprez, J. Campisi, Apigenin suppresses the senescence-associated secretory phenotype and paracrine effects on breast cancer cells. Geroscience 39(2), 161-173 (2017)

26. B. Ruttkay-Nedecky, O. Krystofova, L. Nejdl, V. Adam, Nanoparticles based on essential metals and their phytotoxicity. J. Nanobiotechnol. 15(1), 1-19 (2017)

27. K. Gopinath, S. Kumaraguru, K. Bhakyaraj, S. Thirumal, A. Arumugam, Eco-friendly synthesis of $\mathrm{TiO}_{2}$, Au and Pt doped $\mathrm{TiO}_{2}$ nanoparticles for dye sensitized solar cell applications and evaluation of toxicity. Superlattices Microstruct. 92, 100-110 (2016)

28. S. Shanthi, B.D. Jayaseelan, P. Velusamy, S. Vijayakumar, C.T. Chih, B. Vaseeharan, Biosynthesis of silver nanoparticles using a probiotic Bacillus licheniformis Dahb1 and their antibiofilm activity and toxicity effects in Ceriodaphnia cornuta. Microb. Pathog. 93, 70-77 (2016)

29. A.A. Zahir, A.A. Rahuman, Evaluation of different extracts and synthesised silver nanoparticles from leaves of Euphorbia prostrata against Haemaphysalis bispinosa and Hippobosca maculata. Vet. Parasitol. 187(3), 511-520 (2012)

30. N.T. Ndeh, S. Maensiri, D. Maensiri, The effect of green synthesized gold nanoparticles on rice germination and roots. Adv. Nat. Sci.: Nanosci. Nanotechnol. 8(3), 035008 (2017)

31. Y.F. Lin, M.G. Aarts, The molecular mechanism of zinc and cadmium stress response in plants. Cell. Mol. Life Sci. 69(19), 3187-3206 (2012) 
32. J. Chen, X. Liu, C. Wang, S.S. Yin, X.L. Li, W.J. Hu, M. Simon, Z.J. Shen, Q. Xiao, C.C. Chu, X.X. Peng, H.L. Zheng, Nitric oxide ameliorates zinc oxide nanoparticles-induced phytotoxicity in rice seedlings. J. Hazard. Mater. 297, 173-182 (2015)

33. D. Lin, B. Xing, Root uptake and phytotoxicity of $\mathrm{ZnO}$ nanoparticles. Environ. Sci. Technol. 42(15), 5580-5585 (2008)

34. F. Wang, C.A. Adams, Z. Shi, Y. Sun, Combined effects of ZnO NPs and Cd on sweet sorghum as influenced by an arbuscular mycorrhizal fungus. Chemosphere 209, 421-429 (2018)
Publisher's Note Springer Nature remains neutral with regard to jurisdictional claims in published maps and institutional affiliations. 